\title{
Aquatic Communities and Contaminants in Fish from Streams of the Red River of the North Basin, Minnesota and North Dakota
}

By R.M. Goldstein

U.S. Geological Survey

Water-Resources Investigations Report 95-4047

Contribution from the National

Water Quality Assessment Program 


\section{U.S. DEPARTMENT OF THE INTERIOR \\ BRUCE BABBITT, Secretary \\ U.S. GEOLOGICAL SURVEY \\ Gordon P. Eaton, Director}

For additional information write to:

District Chief

U.S. Geological Survey

2280 Woodale Drive

Mounds View, MN 55112
Copies of this report can be purchased from:

U.S. Geological Survey

Earth Science Information Center

Open-File Reports Section

Box 25286, MS 517

Denver Federal Center

Denver, CO 80225

Information regarding the National Water-Quality Assessment (NAWQA) Program is available on the Internet via the World Wide Web. You may connect to the NAWQA Home Page using the Universal Resource Locator (URL) at:

<URL:http://wwwrvares.er.usgs.gov/nawqa/nawqa_home.html> 


\section{FOREWORD}

The mission of the U.S. Geological Survey (USGS) is to assess the quantity and quality of the earth resources of the Nation and to provide information that will assist resource managers and policymakers at Federal, State, and local levels in making sound decisions. Assessment of waterquality conditions and trends is an important part of this overall mission.

One of the greatest challenges faced by waterresources scientists is acquiring reliable information that will guide the use and protection of the Nation's water resources. That challenge is being addressed by Federal, State, interstate, and local water-resource agencies and by many academic institutions. These organizations are collecting water-quality data for a host of purposes that include: compliance with permits and watersupply standards; development of remediation plans for a specific contamination problem; operational decisions on industrial, wastewater, or water-supply facilities; and research on factors that affect water quality. An additional need for waterquality information is to provide a basis on which regional and national-level policy decisions can be based. Wise decisions must be based on sound information. As a society we need to know whether certain types of water-quality problems are isolated or ubiquitous, whether there are significant differences in conditions among regions, whether the conditions are changing over time, and why these conditions change from place to place and over time. The information can be used to help determine the efficacy of existing water-quality policies and to help analysts determine the need for, and likely consequences, of new policies.

To address these needs, the Congress appropriated funds in 1986 for the USGS to begin a pilot program in seven project areas to develop and refine the National Water-Quality Assessment (NAWQA) Program. In 1991, the USGS began full implementation of the program. The NAWQA Program builds upon an existing base of waterquality studies of the USGS, as well as those of other Federal, State, and local agencies. The objectives of the NAWQA Program are to:
- Describe current water-quality conditions for a large part of the Nation's freshwater streams, rivers, and aquifers.

- Describe how water quality is changing over time.

- Improve understanding of the primary natural and human factors that affect water-quality conditions.

This information will help support the development and evaluation of management, regulatory, and monitoring decisions by other Federal, State, and local agencies to protect, use, and enhance water resources.

The goals of the NAWQA Program are being achieved through investigations of 60 of the Nation's most important river basins and aquifer systems, which are referred to as study units. These study units are distributed throughout the Nation and cover a diversity of hydrogeologic settings. More than two-thirds of the Nation's freshwater use occurs within the 60 study units and more than two-thirds of the people served by public watersupply systems live within their boundaries.

National synthesis of data analysis, based on aggregation of comparable information obtained from the study units, is a major component of the program. This effort focuses on selected waterquality topics using nationally consistent information. Comparative studies will explain differences and similarities in observed waterquality conditions among study areas and will identify changes and trends and their causes. The first topics addressed by the national synthesis are pesticides, nutrients, volatile organic compounds, and aquatic biology. Discussions on these and other water-quality topics will be published in periodic summaries of the quality of the Nation's ground and surface water as the information becomes available.

This report is an element of the comprehensive body of information developed as part of the NAWQA Program. The program depends heavily on the advice, cooperation, and information from many Federal, State, interstate, Tribal, and local agencies and the public. The assistance and suggestions of all are greatly appreciated.

Robert M. Hirsch Chief Hydrologist 
Blape 


\section{Contents}

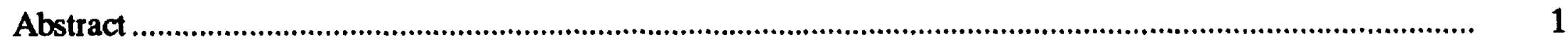

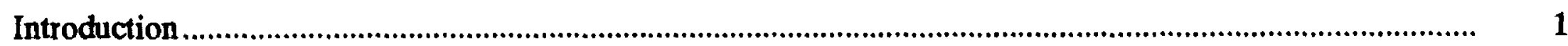

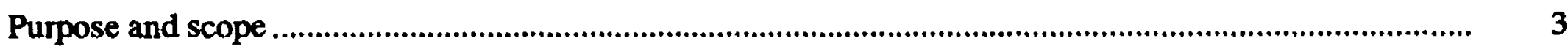

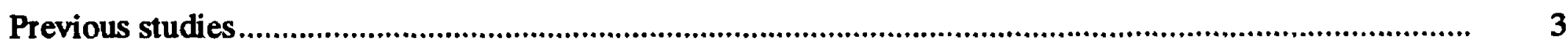

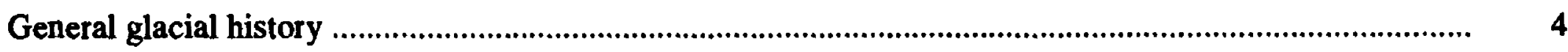

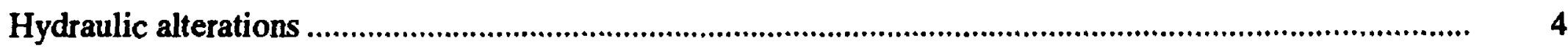

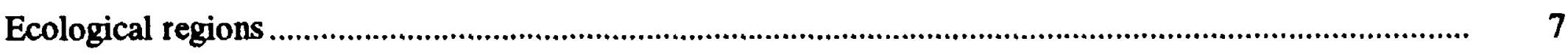

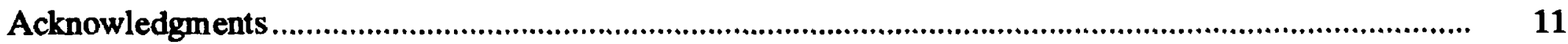

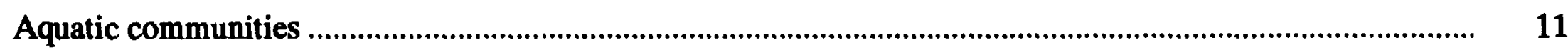

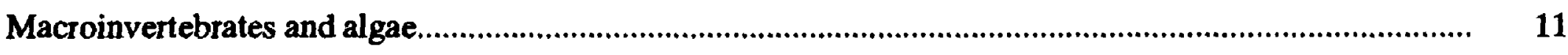

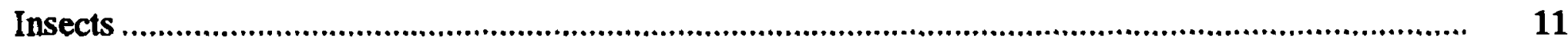

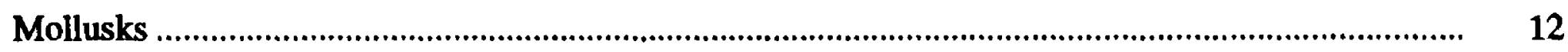

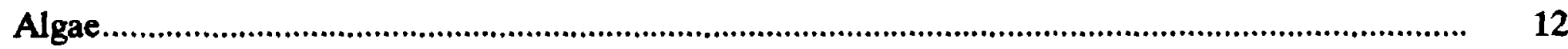

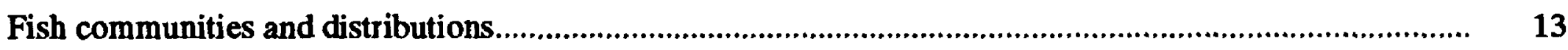

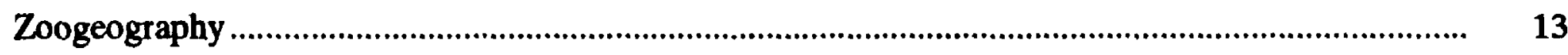

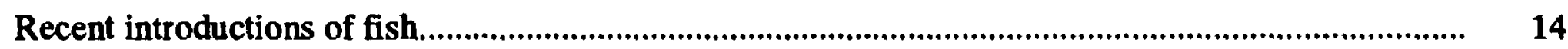

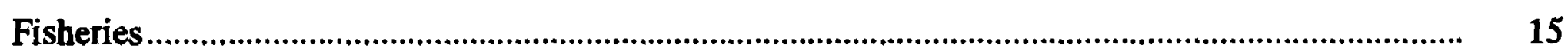

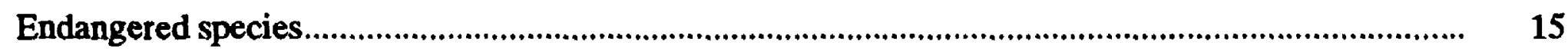

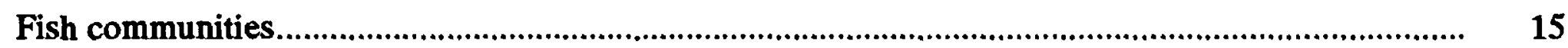

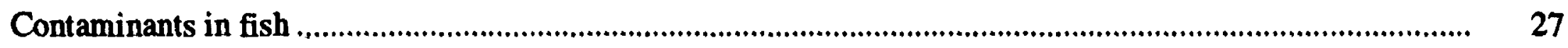

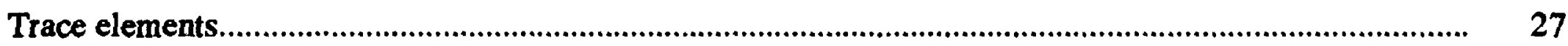

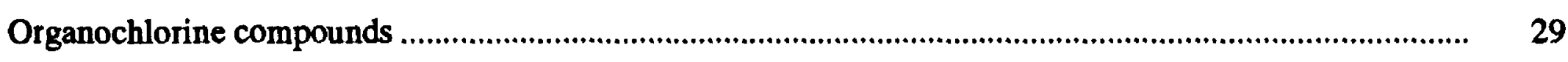

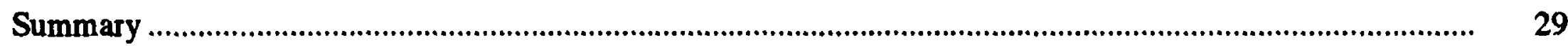

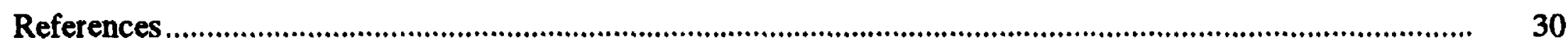

\section{Illustrations}

Figure 1-5. Maps showing:

1. Major rivers in the Red River of the North Basin .............................................................. 2

2. Portions of the United States and Canada covered by glacial Lake Agassiz .......................... 5

3. Locations of dams and reservoirs in the Red River of the North Basin .................................... 6

4. Areas of wetlands and drainage ditches in the Red River of the North Basin ........................... 8

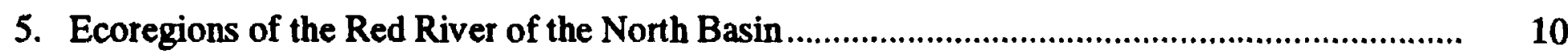

6-8. Graphs showing:

6. Species richness of rivers that flow through one, two, or three ecoregions,

Red River of the North Basin

7. Relation of species richness and drainage basin area for streams in the

Red River of the North Basin

8. Relation of species richness, drainage basin area, and the number of ecoregions a river flows through in the Red River of the North Basin. 


\section{Illustrations-Continued}

9. Dendograph showing average linkage cluster analysis for species composition of streams in the Red River of the North Basin.

10-11. Graphs showing:

10. Percentage of species within trophic groups among river groups identified by cluster analysis, Red River of the North Basin

11. Percentage of species within taxonomic groups among river groups identified by cluster analysis, Red River of the North Basin

\section{Tables}

Table 1. Sources of biological information for the Red River of the North Basin

2. Selected features of the ecoregions of the Red River of the North Basin

3. Aquatic mollusks of the Red River of the North Basin in North Dakota and their primary habitats; only lentic habitats are presented

4. Fish distributions in the Red River of the North and its major tributaries

5. Fishes with geographically distinct distributions in the Red River of the North Basin

6. Trace element concentrations in fish collected from the Red River of the North at Noyes, Minnesota, 1978 through 1986

\section{Conversion Factors and Abbreviations}

\section{Multiply}

meter (m)

kilometer (km)

square kilometer $\left(\mathrm{km}^{2}\right)$

cubic meter $\left(\mathrm{m}^{3}\right)$

cubic kilometer $\left(\mathrm{km}^{3}\right)$

degree Celsius $\left({ }^{\circ} \mathrm{C}\right)$
By

3.281

.6214

.3861

35.31

.000247

.2399

$1.8\left({ }^{\circ} \mathrm{C}\right)+32$
To obtain

foot

mile

square mile

cubic foot

acre-foot

cubic mile

degree Fahrenheit $\left({ }^{\circ} \mathrm{F}\right)$ 


\title{
Aquatic Communities and Contaminants in Fish from Streams of the Red River of the North Basin, Minnesota and North Dakota
}

\author{
By Robert M. Goldsteln
}

\begin{abstract}
Available data on the ecology of aquatic organisms in the Red River of the North Basin, a study unit of the U.S. Geological Survey's National Water-Quality Assessment program, were collated from numerous sources. Lack of information for invertebrates and algae precluded a general summary of distribution and ecology throughout the basin. Data on fish species distributions in the major streams of the Red River of the North Basin were analyzed based on the drainage area of the stream and the number of ecoregions the stream flowed through. Species richness increased with both drainage area (log drainage area in square kilometers, $R^{2}=0.41, p=0.0055$ ) and the number of ecoregions a river flowed through. However, theses two factors are autocorrelated because the larger the drainage, the more likely that the river will flow through more than one ecoregion. A cluster analysis identified five river groups based on similarity of species within the fish community. Analysis of trophic and taxonomic composition provided justification for the cluster groups. There were significant differences $(p=0.05)$ in the trophic composition of the river cluster groups with respect to the number of predator species, omnivore species, benthic insectivore species, and general insectivore species. Although there were no significant differences in the number of species in the bass and sunfish family or the sucker family, the number of species in the minnow family and the darter subfamily were different $(p=0.05)$ among the groups identified by cluster analysis. Data on contaminant concentrations in fish from the Red River of the North indicated that most trace elements and organochlorine compounds present in tissues were not at levels toxic to fish or humans. Minnesota and North Dakota have issued a fish consumption advisory based on levels of mercury and (or) PCBs found in some species.
\end{abstract}

\section{Introduction}

The U. S. Geological Survey (USGS) National Water Quality Assessment (NAWQA) program was initiated to define the current status and trends in the quality of the nation's surface and ground-water resources. Because the amount and geographical distribution of these resources are so vast, the major activities of NAWQA will occur within 60 hydrologic systems across the country, which account for about 70 percent of the nation's water use and population served by public water supply. The implementation plan (Leahy and others, 1990) calls for twenty study units to be studied during each of three cycles of NAWQA. Each cycle will include four years of intensive study followed by five years of low-intensity monitoring. Cycles will be initiated at three year intervals.

In 1991, the USGS began to implement the field studies of the first cycle of NAWQA in the Red River of the North (referred to in the text as the Red River) Basin and in 19 other study units across the country. The goals of the program (Cohen and others, 1988) are to: (1) provide a nationally consistent description of current water-quality conditions for a large part of the nation's water resources; (2) define long-term trends in water quality; and (3) identify, describe, and explain the major factors that affect observed water-quality conditions and trends. These goals were established so the program would not only define current conditions, but also determine the reasons for sbserved conditions and then monitor long-term trends.

The Red River Basin (fig. 1) was selected as a study unit because the basin represents an important hydrologic region where water of good quality is vital to the region's economy and the water quality of the Red River, which flows northward into Manitoba, Canada, is of international concern. Additionally, the Red River Basin is an important agricultural area with a northern location, and with potential interaction between surface and ground water. All these characteristics are essential factors for a complete national assessment of water quality (Stoner, 1991). 

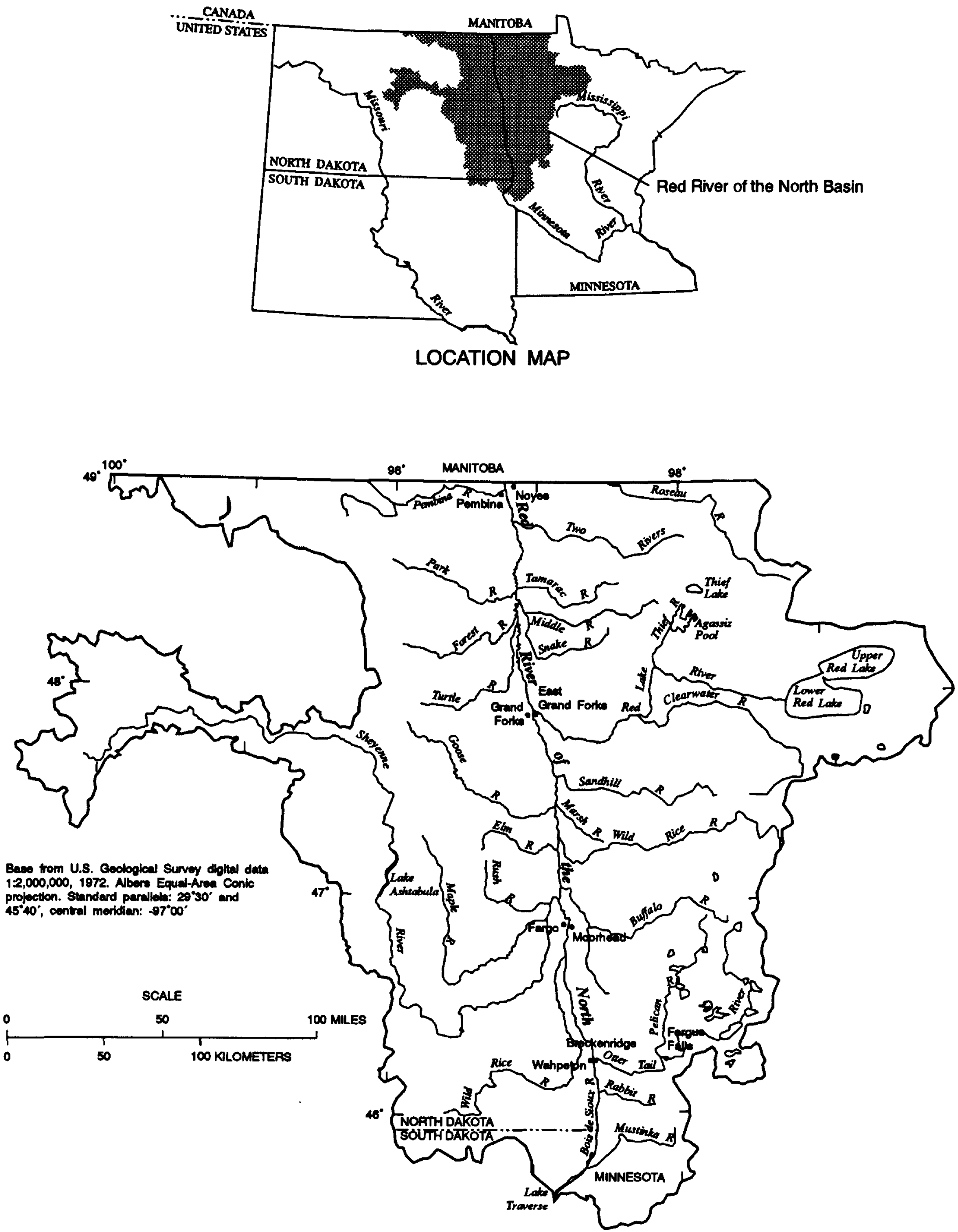

Figure 1. Major rivers in the Red River of the North Basin. 
Table 1.--Sources of biological information for the Red River of the North Basin

\begin{tabular}{lc}
\multicolumn{1}{c}{ Agency } & \multicolumn{1}{c}{ General purpose of biological data } \\
\hline $\begin{array}{l}\text { U.S. Environmental } \\
\text { Protection Agency }\end{array}$ & $\begin{array}{l}\text { Dederal Agencies } \\
\text { and the North Dakota Department of Health, for general research and } \\
\text { regulatory programs. Data include water quality and contaminants in aquatic } \\
\text { organisms. }\end{array}$
\end{tabular}

U.S. Fish and Wildlife Service

Samples are collected for special projects and to measure trends. Data include contaminant residues (metals and pesticides) in tissues of fish, migratory birds, and other aquatic organisms.

\section{State Agencies - Minnesota}

Department of Health

Some toxic compounds are measured to define the health of public resources. Fish are analyzed for toxic compounds for consumption advisories.

Department of Natural Resources, Fish and Wildlife Division

Pollution Control Agency

Data are collected for regulatory programs.

Universities and Colleges

Data are collected for specific research projects. Records of fish collected for the James Ford Bell Museum of Natural History.

\section{State Agencies - North Dakota}

Department of Health and

Data are collected for regulatory programs.

Consolidated Laboratories,

Water Quality Branch

Game and Fish Department

Data are collected to aid in the management of State game and wildlife.

Universities and Colleges

Data are collected for specific research projects.

NAWQA is using a multidisciplinary approach to assess water quality. The ecology of aquatic biological communities is one of the disciplines which is being used to provide multiple lines of evidence for the assessment (Gurtz, 1994).

\section{Purpose and Scope}

The purpose of this report is to summarize existing information on aquatic biological communities in streams of the Red River Basin. This report includes information from 1893 to 1992 and addresses: (1) the ecology of macroinvertebrates, algae, and fish in Red River Basin streams within the United States, and (2) contaminants in fish. This report provides baseline and historical data to describe the fish communities of the rivers of the Red River Basin. These data are summarized through analyses that provide an overview of aquatic ecology in the basin. Data sources are listed in table 1.

\section{Previous Studies}

The aquatic biological communities of the Red River Basin have not been well studied, particularly with respect to macroinvertebrates and algae. Therefore, this report focuses primarily on the fish communities of the Red River Basin. Both North Dakota Game and Fish 
Department (NDGFD) and Minnesota Department of Natural Resources (MNDNR) have conducted general fishery surveys (North Dakota Game and Fish Department, 1962a, 1962b, 1964, 1975a, 1975b, 1977; Enblom, 1982; Naplin and others, 1977; Reedstrom, 1967; Reedstrom and Carlson, 1969; Ryckman, 1981; Renard and others, 1983 and 1986). Ichthyologists at the University of Minnesota and North Dakota State University have examined fish species distributions and zoogeography in the Red River Basin (Eddy and Underhill, 1974; Underhill, 1957, 1989; Peterka, 1978). While these investigations have documented species distributions in the various rivers of the Red River Basin, there is a significant lack of information on the relative abundances of non-game species from NDGFD and MNDNR surveys; therefore, information regarding the structure of fish communities is minimal.

While some information is available for fish, very little information is available for invertebrates and algae. A few studies have been done on mollusks (Cvancara, 1970 and 1983; Dawley, 1947). Other studies of aquatic invertebrates are lacking other than an in depth ecological study of the Turtle River in North Dakota (Neel, 1985) and a study of riffle invertebrates in the Forest River (Stoaks, 1975). A biological survey of the Otter Tail River by the MNDNR (Hanson and others, 1984) included macroinvertebrate collections. Information on algae is available from Neel (1985) for the Turtle River in North Dakota and appears occasionally in some of the biological surveys conducted by the MNDNR.

The main sources of information for contaminants in fish are from the National Contaminant Biomonitoring Program of the U. S. Fish and Wildlife Service, Minnesota Department of Health, and the U.S. Environmental Protection Agency.

\section{General Glacial History}

In terms of geologic time, the Red River Basin has not been occupied by aquatic biota very long. About 14,000 years before present (BP), the continental glacier covered the basin (Wright, 1972a) precluding the existence of most organisms. The history of ice advances and retreats, combined with the various aquatic connections to glacial-period biotic refugia, account for the biological communities inhabiting the basin today. These communities have been modified by cultural activities and hydraulic alterations in the basin during the last 150 years of human settlement.

During the last 12,000 years, the Red River Basin has been open to immigration by aquatic biota from the Mississippi, eastern Great Lakes, and Alaska refugia
(Eddy and others, 1972). As glacial ice retreated northward, due to warming climatic conditions, a large inland lake, glacial Lake Agassiz (fig. 2), was formed about 12,000 BP (Wright, 1972a). The lake alternately drained through glacial River Warren to the south (the present day Minnesota River) to the Mississippi River Basin, to the west to the Alaska refugium, and to the east to the Great Lakes, depending on both water levels and the extent of ice coverage.

By 11,500-11,000 BP, ice had retreated north into Canada and Lake Agassiz drained through River Warren. When water levels decreased sufficiently in Glacial Lake Agassiz, drainage through River Warren was blocked at a moraine of slight elevation between the current Red River and Minnesota River valleys (Wright, 1972a and 1972b; Underhill, 1986).

Further retreat of the ice opened a drainage channel through the Nipigon Basin in Ontario into the Great Lakes. When ice advanced and covered the Nipigon outlet about 9,900 BP, the lake again drained through River Warren. Water levels dropped and the southern outlet was closed about 9,200 years BP (Underhill, 1989; Wright 1972a). The Great Lakes outlet finally closed about 8,500 BP, leaving the Red River Basin and drainage patterns observed today (Underhill, 1989).

\section{Hydraulic Alterations}

During the last 150 years, the Red River Basin has been settled and become a major agricultural area in the United States. Approximately 74 percent of the land is devoted to agriculture; 66 percent is for crops, (primarily small grains, potatoes, sugar beets, and sunflowers) and 8 percent is pasture or rangeland. The topographic relief is slight, with only a $525 \mathrm{~m}$ difference in elevation across the United States portion of the basin. Stoner and others (1993) present a detailed description of the basin.

The combination of agricultural activities with the low relief in topography has led to the construction of dams and drainage ditches, the former to reduce flooding and the latter to remove excess water from agricultural land. Both of these constructions have affected the aquatic biota of the Red River Basin. The majority of dams are small, low-head dams for flood control, water supply, and recreation. There are only a few large dams in the Red River Basin: Baldhill Dam at Lake Ashtabula on the Sheyenne River, North Dakota; Orwell Dam on the Otter Tail River, Minnesota; Lake Traverse on the Bois de Sioux River, South Dakota and Minnesota; and Upper and Lower Red Lakes, Minnesota (Stoner and others, 1993). These facilities are operated by the U.S. Army Corps of Engineers. 


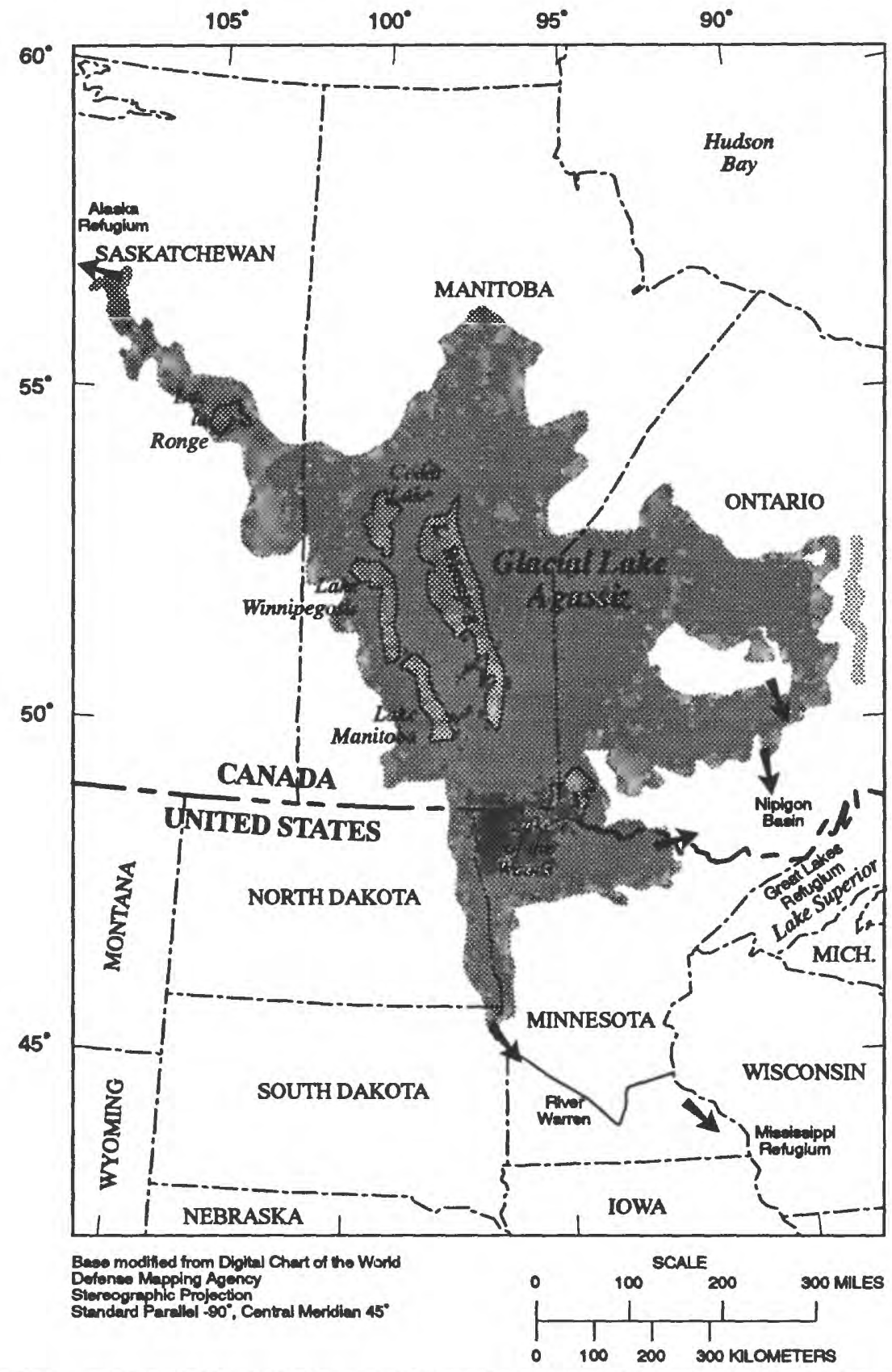

Figure 2. Portions of the United States and Canada covered by glacial Lake Agasslz [arrows Indicate known drainageways or connectives] (modified from Eddy and others, 1972), Red Rlver of the North Basin.

Additionally, there are approximately 450 other smaller dams in the basin (fig. 3). The sizes of the impoundments vary in storage capacity from less than $2400 \mathrm{~m}^{3}$ to $2232 \mathrm{~km}^{3}$. The effects of dams on fish and other aquatic biota have been documented and reviewed in numerus publications (Neel, 1963; Spence and
Hynes, 1971; Erman, 1973; Baxter, 1977; Edwards, 1978).

Dams in the Red River Basin have variable effects on fish depending on the size of the dam, the size of the impoundment created by the dam, its location longitudinally in the river, and the location of discharge 


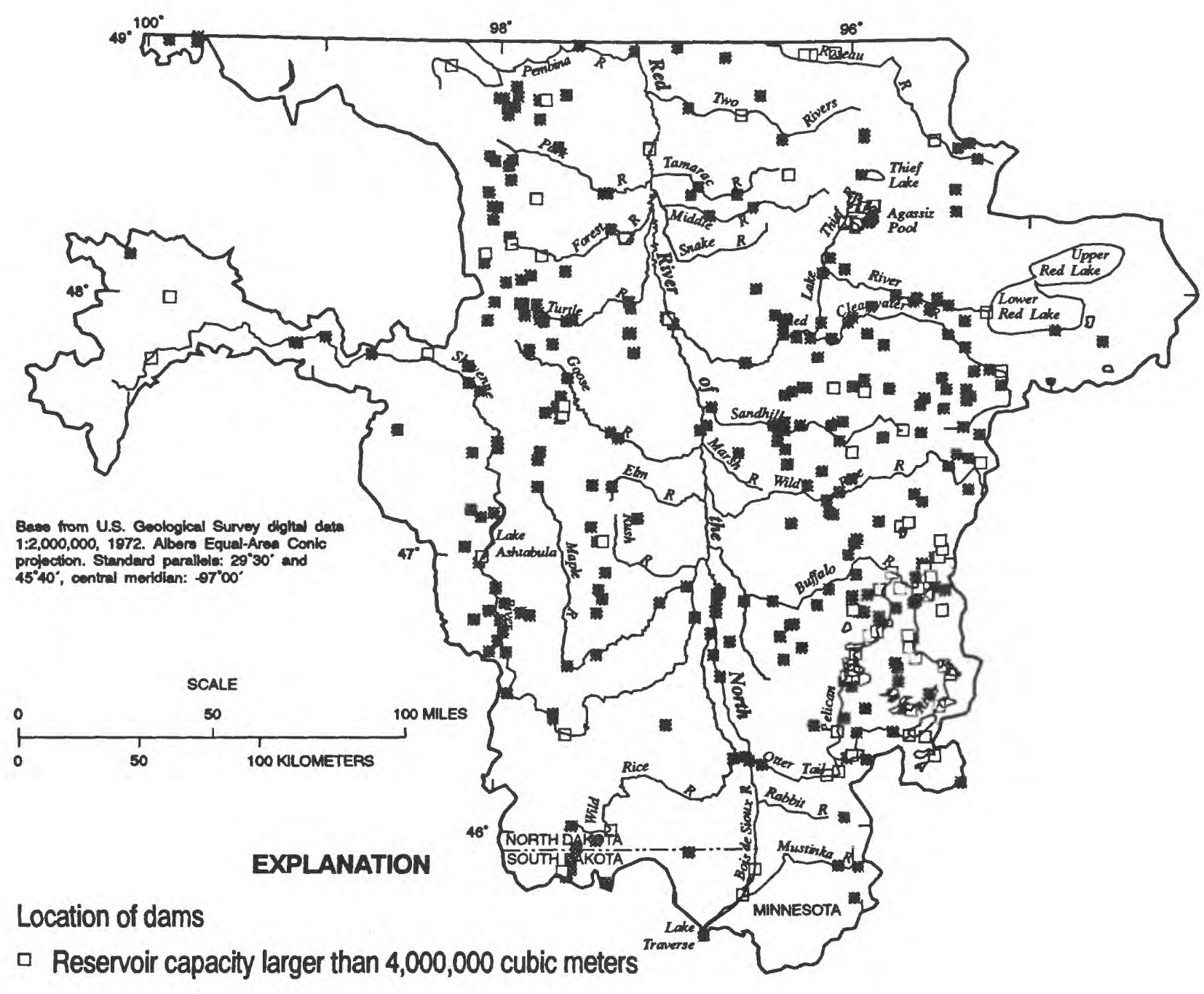

- Reservoir capacity smaller than 4,000,000 cubic meters

Figure 3. Locations of dams and reservoirs in the Red River of the North Basin (modified from
Stoner and others, 1993 and data from Red River Watershed Management Board).

(over the top of the dam or spillway or through the bottom of the dam).

Depending on the size, the dam may be a barrier to passage by fish. This would prevent species from expanding their ranges upstream of the dam. In most cases, this has not been significant. During spring flooding, many of the small, low head dams are overtopped by high water and therefore have not presented a barrier to fish during spring spawning migrations. However, species have been excluded from some streams by dams located near the confluence with the Red River or from upstream reaches by other dams along the river. A dam on the Buffalo River, Minnesota was considered an effective barrier against upstream carp (Cyprinus carpio) migration by Reedstrom (1967), and carp and redhorse (Moxostoma spp.) are not found in the Sheyenne River above Baldhill Dam (Owen and others, 1981; Peterka, 1978)). Peterka (1978) and Ryckman (1981) report 31 and 30 species, respectively, above Baldhill Dam in the upper Sheyenne River and both report 49 species below the dam. A MNDNR survey of the Otter Tail River in 1978 (Hanson and others, 1984) documents 22 dams on the stream and classifies $\mathbf{2 0}$ as barriers to fish. In a similar survey of the Red Lake River, Renard and others (1983) found a total of 38 species of fish in the river, 23 above the most upstream dam and 30 below that dam. 
The size of the impoundment created by a dam can affect both the species composition and abundance of fish in a river. A major factor is the amount of lentic habitat created. Impoundments tend to be a favorable habitat for species generally considered pond or lake species (most members of the families Centrarchidae (bass and sunfish), some Ictaluridae (catfish and bullheads), and some Percidae (perch)). In the Sheyenne River, there is an active sport fishery for yellow perch (Perca flavescens) and bullheads (Amieurus spp.) which Peterka (1978) indicates are uncommon in unimpounded river sites. Most of the bass and sunfish are considered pool species (Karr, 1981), and small impoundments mimic natural riverine pool habitat. In some cases, impoundments act to increase the abundance of pool-type species by providing new habitat from which the pool species emigrate to other parts of the river (Schlosser, in press).

The majority of the low-head dams in the Red River Basin have created small, run of the river impoundments. These impoundments discharge water over the top of the dam. Thus, the quality of the water is altered very little by the impoundment. There may be a slight increase in temperature due to residence time and lack of shading in the impoundment; there may be a slight reduction in the concentration of suspended particulates due to some minor settling in the impoundment; and there may be an increase in the amount of organic matter added to the flow by increased primary production in the pool-like environment (Hynes, 1970). In contrast, large impoundments may have significant effects on the quality of water being discharged, particularly if the discharge is through the bottom of the dam. Changes to water quality include lower water temperatures, reduced dissolved oxygen, lower concentrations of suspended particulates, and increased concentrations of iron, manganese, hydrogen sulfide, and other chemical constituents (Grizzle, 1981; Hynes, 1970). The effects of these changes to water quality on fish may include changes in species composition and relative abundance, physiological stress from low dissolved-oxygen concentrations and temperature either singly or in combination with higher concentrations of certain chemical constituents and pathogens such as parasites, bacteria, and viruses (Grizzle, 1981; Hynes, 1970).

Channelization has numerous effects on aquatic biota, primarily related to loss of habitat and substrate diversity, changes in the thermal and hydrologic regimes, disruption of organic-matter processing, and alteration of fluvial geomorphic processes (Hynes, 1970; Etnier, 1972; Gelroth and Marzolf, 1978; Hughes and Gammon, 1987).
Agricultural development in the Red River Basin has included the excavation of a massive network of drainage ditches (fig. 4). The low topographic relief is not conducive to rapid runoff of spring snow melt or precipitation. Since the late 1800 's, an extensive ditch and canal program has resulted in construction of more than $12,000 \mathrm{~km}$ of drainage ditches in the Minnesota counties of the Red River Basin (U.S. Geological Survey, 1974). Ditching in North Dakota has not been as extensive as in Minnesota. Ditches drain over 36 percent of the land in the Red River Basin in Minnesota. The ditching is so extensive that Waters (1977) stated, "No area on earth has been so intensively drained for agriculture as the Red River Valley." During the MNDNR survey of the Roseau River (Enblom, 1982), 44 percent of the tributaries entering the river were classified as ditches with field drainage as the source. Not only were ditches excavated, but existing stream channels were straightened and channelized. This has caused loss of small headwater streams (first and second order streams as defined by Strahler, 1957). Many of the small headwater streams have been lost to agriculture and have been incorporated into fields for crop production (Fandrei and others, 1988). First and second order streams are important ecologically as the sites of initial organic matter processing and transport (Vannote and others, 1980; Minshall and others, 1983; Bott and others, 1985; Wiley and others, 1990).

\section{Ecological Regions}

The Red River Basin occupies approximately 90,000 $\mathrm{km}^{2}$. There are areas within the Red River Basin which have similar land use, topography, soils, precipitation, natural vegetation, hydrology and other factors. Omernik and Gallant (1988) have classified similar ecological areas as ecoregions. Ecoregions are considered to be ecologically homogeneous based on features including distributions of native plant and animal species, soil type, geology, land cover including crops and wetlands, and physiography. Most of the land area in the Red River Basin consists of four ecoregions (fig. 5) and small portions of two others that are on the periphery of the basin. From west to east they are:

\section{Northwestern Glaciated Plains}

\section{Northern Glaciated Plains}

\section{Red River Valley}

\section{North Central Hardwood Forest}

\section{Northern Minnesota Wetlands}

6. Northern Lakes and Forests 


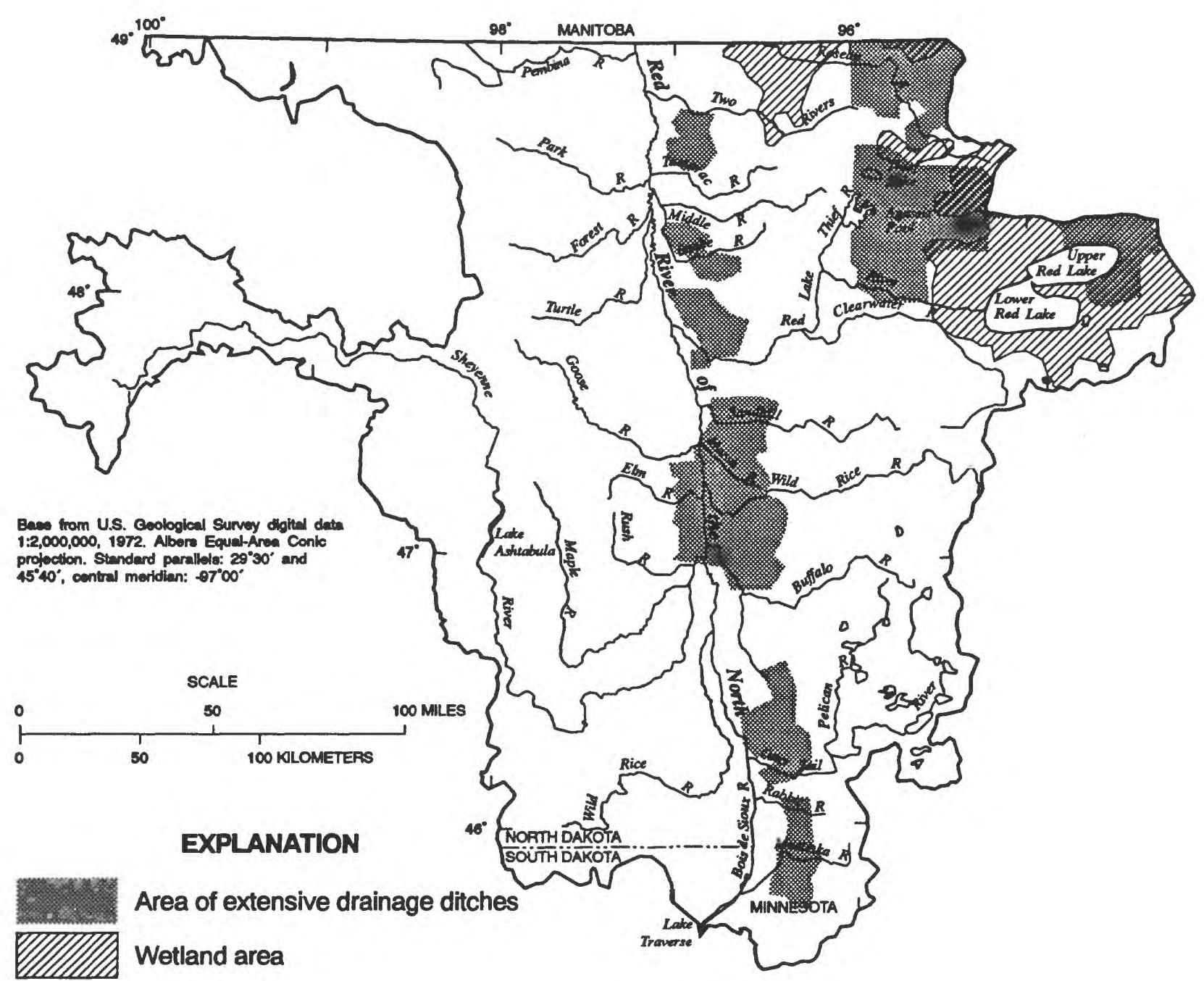

Flgure 4. Areas of wetlands and dralnage ditches in the Red River of the North Basin (modified from Stoner and others, 1993).

The Northwestern Glaciated Plains constitutes a minor portion of the Red River Basin, and therefore is included with the Northern Glaciated Plains for purposes of this report. Whereas many of the features are similar between one or two of the ecoregions, there are sufficient differences to separate them. The general characteristics of each ecoregion are presented in table 2.

One of the most significant discriminators for the rivers in the various ecoregions is stream gradient. Stream gradient provides the potential energy which controls the geomorphological processes of channel maintenance, bed load transport, and hence the formation of substrates and the various physical habitats available for aquatic biota. Although stream gradients tend to be low to moderate in all the ecoregions, minor differences in parent material have contributed to major differences among the rivers in the ecoregions. There are substantial differences in the relative abundance of geomorphological units (riffles, pools, and runs) among ecoregions. The dominant substrates differ in relation to stream gradient, parent material, and the abundance of geomophological units. Generally, as the overall stream gradient decreases, the abundance of riffles and large, coarse substrate material decreases, whereas long runs or glides with finer substrate materials increase. Those ecoregions lateral to the Red River Valley ecoregion tend to contain rivers and streams with more abundant cobble and gravel. Substrates in the Red River Valley tend to be dominated by sand, clay, and silt. 


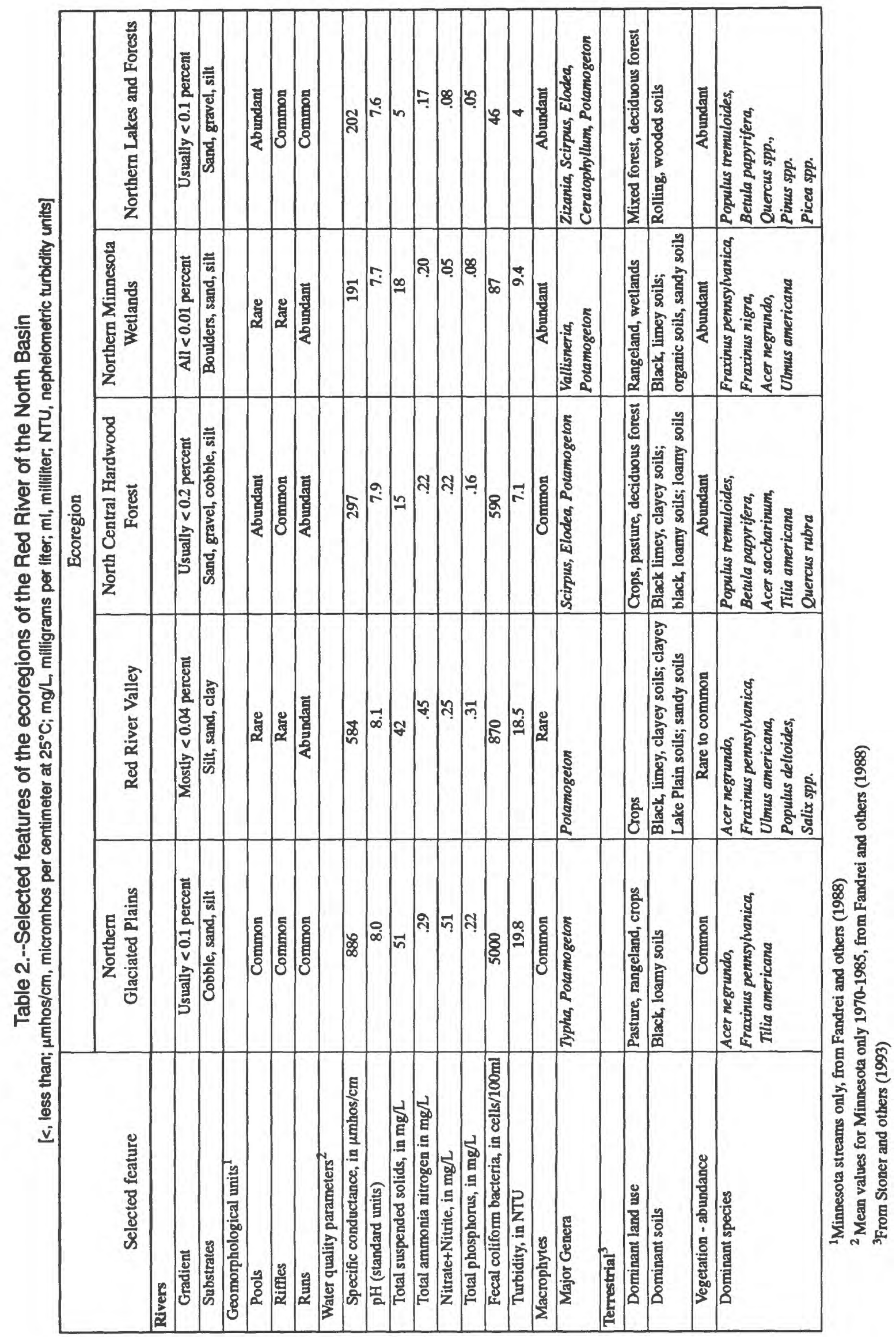




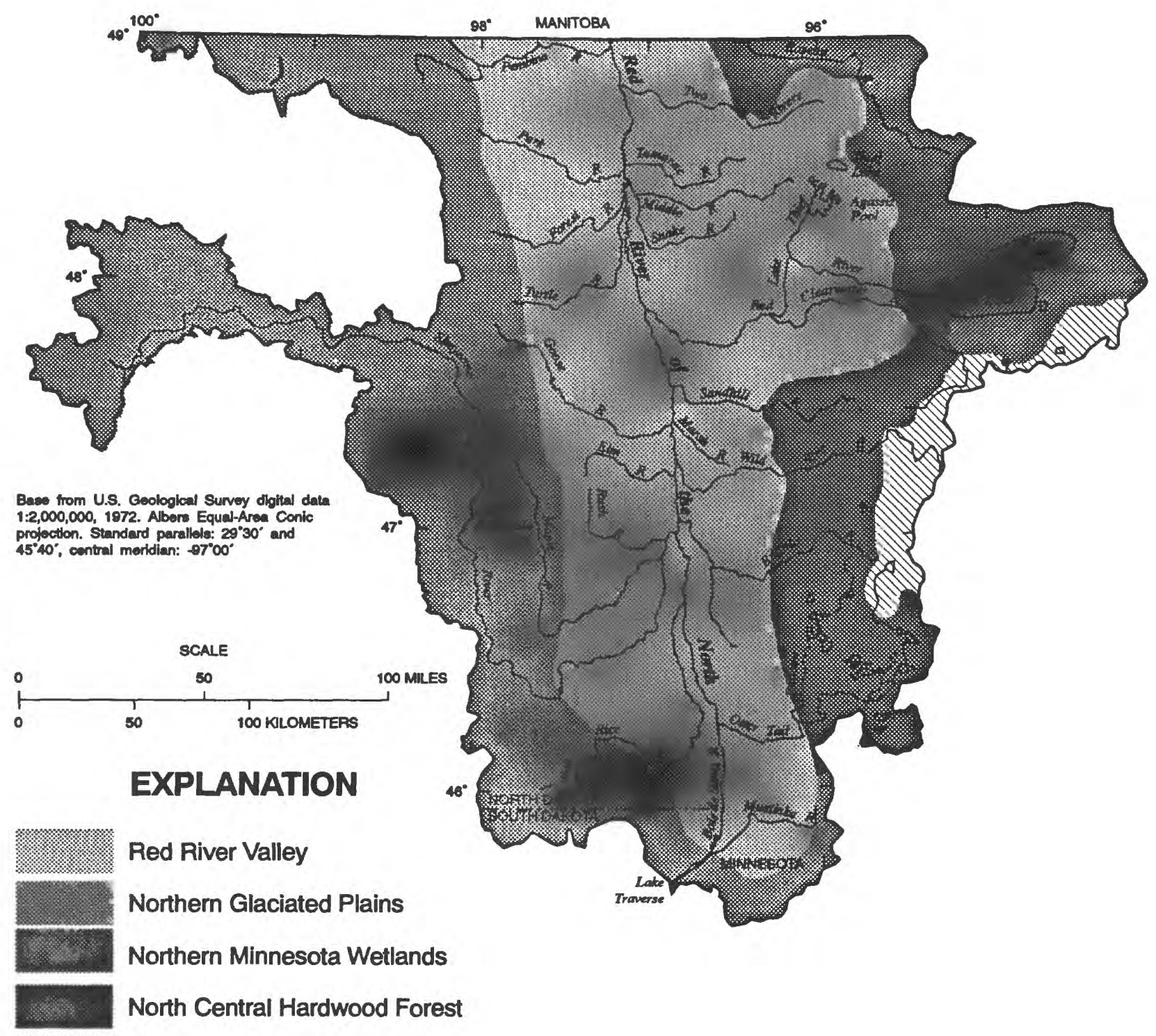

Northern Lakes and Forests

\section{Figure 5. Ecoregions of the Red Rlver of the North Basin (modified from Omernik, 1987).}

Some differences are evident in water-quality conditions (water-quality data in table 2 are from Minnesota only (Fandrei and others, 1988)). Ecoregions with low stream gradient or more erodible soils (Red River Valley, Northern Glaciated Plains), tend to have higher specific conductances, total suspended-solids concentrations, and turbidity than other ecoregions. Ecoregions in which agriculture and livestock production are major land uses (Northern Glaciated Plains, Red River Valley, and North Central Hardwood
Forest) contain rivers where nutrient concentrations and coliform levels tend to be higher than other ecoregions. Three ecoregions have an abundance of streams that flow through lakes, ponds, or wetlands (North Central Hardwood Forest, Northern Lakes and Forests, and Northern Minnesota Wetlands). These rivers are characterized by water chemistry conditions that reflect the presence of the lentic systems (lower turbidity and lower suspended-solids concentrations from the settling of particulates in the lentic areas). Fandrei and others 
(1988) concluded from statistical analyses of water chemistry results that the agricultural ecoregions in Minnesota that include the Red River Valley and Northern Glaciated Plains showed the greatest effect on water-quality characteristics from land use.

Whereas all the rivers in the Red River Basin support aquatic macrophytes to some degree, those in the ecoregions with flow-through lakes, ponds, and wetlands support a more diverse assemblage dominated by a mixture of both lentic and lotic forms. A MNDNR biological survey (Enblom, 1982) of the Roseau River (the major river in the Northern Minnesota Wetlands) found the dominant macrophytes to include Potamogeton and Vallisneria. Similar surveys of rivers in the North Central Hardwood Forest and the Northern Lakes and Forests (Reedstrom, 1967; Hanson and others, 1984; Renard and others, 1983) indicate that the rivers, which flow through lakes in ecoregions lateral to the Red River Valley, also support more lentic genera such as Elodea, Ceratophyllum, Scirpus, Potamogeton, and Zizania. The abundance of macrophytes decreases in the Red River Valley as a result of decreased light penetration due to higher levels of suspended solids and turbidity (Renard and others, 1986). Some Potamogeton may be found in the shallow areas of the Red River where depth is also a limiting factor, but generally macrophytes are rare.

\section{Acknowledgments}

This report would not have been possible without the help and cooperation of the Federal, State, and local organizations concerned with the aquatic resources of the Red River Basin (table 1). The author thanks Dr. Richard Nelson, Mr. Brent Johnson, and Mr. David Fink, members of the liaison committee of the Red River of the North NAWQA study unit, who provided technical reviews of this report. Additional thanks go to the James Ford Bell Museum of Natural History for providing records of fish from its collection.

\section{Aquatic Communities}

Aquatic communities consist of plant and animal populations. Community composition changes spatially and temporally in aquatic ecosystems in response to (1) physical conditions such as day length, temperature, water velocity, (2) chemical conditions such as dissolved oxygen, salinity, and toxic compounds, and (3) biological interactions such as competition and predation.

\section{Macrolnvertebrates and Algae}

Aquatic macroinvertebrates include primarily insects and mollusks. Most orders of insects contain some aquatic forms or aquatic life history stages. Aquatic mollusks include mussels, clams, and snails. Aquatic algae include members of most major algal groups, but are dominated by green algae and diatoms.

\section{Insects}

Neel (1985) studied aquatic ecology, including macroinvertebrates and algae, of the Turtle River. The study area is in the Red River Valley ecoregion and the results may be descriptive of macroinvertebrate and algal communities in other rivers in the ecoregion. Composite benthic macroinvertebrate samples, collected with a Surber sampler, contained 133 taxa in 16 orders and 58 families. Within the composite samples, the total mean density was 6,686 individuals $/ \mathrm{m}^{2}$. The samples were dominated by the caddisfly genera Cheumatopsyche and Hydropsyche, which represented 51 percent of the total sample. Corixid water bugs and elmid water beetles ranked next in abundance and accounted for 8 percent and 7 percent, respectively. Small clams (Pisidium and Sphaerium), mayflies (Stenonema), and midge larvae

(Chironomidae) each represented about 4 percent of the total sample. Stoaks (1975) found a similar community structure in the Forest River, which is also in the Red River Valley ecoregion (fig. 5).

From the results of these two studies, it appears that the macroinvertebrate communities of the Red River Valley ecoregion are composed primarily of filtering and gathering collectors (Cummins and Merritt, 1984). A trophic structure composed primarily of collectors indicates that the majority of the organic matter that feeds the secondary production of the aquatic community is derived either from larger particles (leaves and woody debris) that have been processed into small particles by upstream biota, or from small particles (algal cells) produced locally.

The MNDNR biological survey of the Otter Tail River (Hanson and others, 1984) obtained data on macroinvertebrate communities from the three ecoregions the river flows through (from upstream to downstream) the Northern Lakes and Forests, the North Central Hardwood Forest, and the Red River Valley). The MNDNR conducted quantitative invertebrate sampling with a petite ponar dredge during 1979 and 1982. Sampling sites were selected based on substrate type (sand, gravel-sand, rubble-gravel, and gravel with aquatic vegetation). Gravel-sand and sand are the dominant substrates (along with silt) in the Red River Valley ecoregion portion of the river. Gravel with 
aquatic vegetation is more representative of the substrates in the other two ecoregions.

Results from four replicate samples indicated gravelsand, and sand substrata contained fewer taxa and specimens than the gravel with aquatic vegetation substrate. Total numbers of taxa ranged from 14 from sand substrates, to 34 from gravel-sand, to 68 from gravel with aquatic vegetation. The abundance of specimens found from all samples were $160,2,185$, and 6,573 individuals $/ \mathrm{m}^{2}$ from those substrates, respectively. The abundance of invertebrates from the gravel with aquatic vegetation from the Otter Tail River was similar to the abundance of invertebrates determined by Neel (1985) for the Turtle River even though the substrate in the Turtle River was a mixture of stones, sand, and gravel. Some caution should be used when comparing macroinvertebrate data from these studies, considering the differences in sampling equipment and substrates.

A total of 242 taxa from 23 orders and 68 families were collected by both qualitative and quantitative sampling throughout the Otter Tail River (Hanson and others, 1984). According to the number of taxa, the most abundant orders were Diptera (40 percent), Trichoptera (20 percent), Ephemeroptera ( 8 percent), and Coleoptera (8 percent). Midges (Chironomidae) were the most abundant family of Diptera. In quantitative sampling, the most abundant midge genus from gravel with aquatic vegetation was Parametriocnemus, whereas Robackia, Paratendipes, and Cordites were most abundant from sand.

In quantitative sampling from sand and gravel with aquatic vegetation, hydropsychid caddisflies were 32 and 26 percent, respectively, of the total individuals collected. Hanson and others (1984) noted that species of the genera Cheumatopsyche, Hydropsyche, and Symphitopsyche were common in the upper reaches of the Otter Tail River (Northern Lakes and Forests and North Central Hardwood Forest ecoregions), whereas in the Red River Valley ecoregion, the appearance of Potamyia flava and Hydropsyche bidens correlated with the changes in the river from a fairly clear woodland river to a low gradient, turbid river.

The most abundant taxa of Ephemeroptera (mayflies) from gravel with aquatic vegetation were Pseudocloen (Baetidae) and Potamanthus (Potamanthidae). Hexagenia (Ephemeridae) was present in silt.

\section{Mollusks}

Cvancara (1983) lists 12 species of pelecypod mussels and 8 species of sphaeriid clams for the North Dakota part of the Red River Basin (table 3). The most prevalent mussels were Anodonta grandis, Lasmigona complanata, and Lampsilis radiata. The most prevalent pill clams were Sphaerium lacustre, $S$. striatinum, $S$. transversum, and Pisidium compressum. The most abundant species were Lampsilis radiata and $A$. grandis. Cvancara (1983) applied a cluster analysis to similarity coefficients developed from species occurrence data. The cluster analysis identified four species associations which corresponded to four of the five general habitat classifications he used to describe mollusk habitats in North Dakota. One of the habitat classes was large, permanent rivers in the Hudson Bay Drainage, which consist of the Red River of the North and the Sheyenne River below Lake Ashtabula. The species association that dominated this habitat class he termed the Amblema plicata-Fusconaia flava association. This association consisted of $A$. plicata, $F$. flavia, Strophitus undulatus, Lampsilis ovata, $L$. compressa, Sphaerium transversum, Quadrula quadrula, Ligumia recta, and Proptera alata. In a prior study, Cvancara (1970) attributed a decrease in mollusks at three locations on the Red River of the North to water pollution.

The MNDNR survey of the Otter Tail River (Hanson and others, 1984) reported 11 species of mussels below Orwell Dam. The major species associations in the lower Otter Tail River were similar to those of Cvancara's (1983) large river group, however, four different species (Actinonaias carinata, Lampsilis ventricosa, Lasmigona costata, and Strophitus undulatus) were found in the Otter Tail River. The results of Hanson and others (1984) were similar to the study of Dawley (1947), but included the first record of Elliptio dilatatus from the Red River Basin.

\section{Algae}

Neel (1985) characterized five algal communities associated with various habitats in the Turtle River in North Dakota. Three communities were found in riffles and at the heads and tails of pools, one on sandy bottoms under low stream velocities, and one in still-water areas. Diatoms were the most widespread group present in all habitats. Filamentous green algae, Cladophora and Spirogrya, were dominant at various times in other habitats-Cladophora in pool heads and tails and Spirogrya in still-water areas. Riffle, fast-water communities were successional. Early in the year diatoms dominated the riffle areas; the most abundant diatom was Gomphonema olivaceum. This community was comprised of unicellular forms epilithic in the riffle areas. Cladophora appeared just after the first growth of diatoms and was present until late in the fall. The third 
Table 3.--Aquatic mollusks of the Red River of the North Basin in North Dakota and their primary habitats; only lentic habitats are presented.

[Modified from Cvaranca, 1983]

\begin{tabular}{|c|c|c|c|}
\hline \multirow[b]{2}{*}{ Species } & \multicolumn{3}{|c|}{ Lentic habitat } \\
\hline & $\begin{array}{l}\text { Intermittent } \\
\text { streams }\end{array}$ & $\begin{array}{l}\text { Small perennial } \\
\text { streams }\end{array}$ & Rivers ${ }^{1}$ \\
\hline \multicolumn{4}{|l|}{ Mussels (unionacean bivalves) } \\
\hline Amblema plicata & & & $\mathbf{X}$ \\
\hline Fasconaia flava & & & $\mathbf{X}$ \\
\hline Quadrula quadrula & & & $\mathbf{X}$ \\
\hline Anodonta grandis & & $\mathbf{X}$ & \\
\hline Anodontoides ferussacianus & & $\mathbf{X}$ & \\
\hline Lasmigona complanata & & $\mathbf{X}$ & \\
\hline L. compressa & & $\mathbf{X}$ & \\
\hline Strophitus undulatus & & & $\mathbf{X}$ \\
\hline Lampsilis ovata & & & $\mathbf{X}$ \\
\hline L. radiata & & $\mathbf{X}$ & $\mathbf{X}$ \\
\hline Liguma recta & & & $\mathbf{X}$ \\
\hline Proptera alata & & & $\mathbf{X}$ \\
\hline \multicolumn{4}{|l|}{ Pill Clams (sphaeriid bivalves) } \\
\hline Sphaerium (Musculium) lacustre & & $\mathbf{X}$ & \\
\hline S. (M.) transversum & & $\mathbf{X}$ & $\mathbf{X}$ \\
\hline S. (Sphaerium) simile & & $\mathbf{X}$ & \\
\hline S. (S.) striatinum & & $\mathbf{X}$ & \\
\hline Pisidium (Cyclocalyx) casertanum & $\mathbf{X}$ & $\mathbf{X}$ & \\
\hline$P .(C$.$) compressum$ & & $\mathbf{X}$ & \\
\hline P. (C.) nitidum & & $\mathbf{X}$ & \\
\hline P. (C.) ventricosum & $\mathbf{X}$ & & \\
\hline
\end{tabular}

${ }^{1}$ Red River of the North and Sheyenne River below Lake Ashtabula.

riffle group became dominant in the fast-water habitats as the water warmed and consisted of filamentous diatoms. The most abundant form was Diatoma vulgare. This community grew not only on rocks and sand, but also with its filaments intertwined with those of the filamentous alga, Cladophora. In shaded areas another diatom group was identified and was dominated by Nitzschia linearis. The filamentous green alga, Spirogyra, inhabited the slow water areas. These algal taxa are indicative of moderate nutrient enrichment and are alkaliphilous (S. D. Porter, U.S. Geological Survey, written communication, 1994).

\section{Fish Communities and Distributions}

The fish communities of the Red River Basin have developed and changed since the retreat of the last glacier and the draining of Glacial Lake Agassiz. The current communities consist of species which either migrated into the basin or were introduced for sport or recreational fishing.

\section{Zoogeography}

Based on comparisons of species found within the various drainage systems in Minnesota, Underhill (1989) presents strong evidence that the major source of fish species to the Red River Basin was through the River Warren connection to the Mississippi refugium. The Red River drainage has 73 species (of 75 total native species) in common with the Mississippi River Basin.

The other two species (lake white fish, Corigonus clupeaformis, and the cisco, C. artedi) are cold-water 
species and not found in the lower Mississippi River Basin but could have immigrated from either the eastern Great Lakes or Alaskan refugia.

The fishes and mollusks (Elson, 1967) and other aquatic invertebrates of the Red River Basin are probably relatively recent arrivals. Their current distributions in the basin are the result of colonization of habitats produced by climatic changes and uncovered by glacial activity. Fish in the Red River Basin are still in the process of expanding ranges, colonizing new areas, and changing distributions through immigration and emigration. Some species may have been extirpated due to human activities. For example, the lake sturgeon (Acipencer fulvescens) has only been reported from four collections in the Red River Basin (Eddy and others, 1972), none within the last 20 years. The longnose gar (Lepisosteus osseus) was reported by Woolman (1895) from the Otter Tail River but has not been collected since 1895 (Eddy and Underhill, 1974).

Comparison of distributional data for several species as reported by Eddy and others (1972) with more recent distributional information (Anderson and others, 1977; Peterka, 1978 and 1991; Ryckman, 1981; Hanson and others, 1984; Renard and others, 1986; and recent collections from the James Ford Bell Museum of Natural History, written commun., 1992) indicate range extensions for numerous species in the Red River Basin. Anderson and others (1977) revised distributions of twelve species in Minnesota. Ten of the twelve changes involve species in the Red River Basin including three species new to the basin. The authors dismiss illegal and accidental introduction of the previously uncollected species and speculate on the source and movement of the species into the Red River Basin.

The bigmouth buffalo (Ictiobus cyprinellus) is in the process of expanding its range into the Red River Basin (Hubbs and Lagler, 1958) and recently has been reported throughout the basin (Ryckman, 1981; James Ford Bell Museum of Natural History collection records). The northern hogsucker (Hypentelium nigricans) was not reported from the Red River Basin by either Eddy and others (1972) or by Eddy and Underhill (1974). The species was first collected from the Otter Tail River during a MNDNR survey (Hanson and others, 1984). The weed shiner (Notropis texanus) was first reported in the Red River Basin in the Otter Tail River by Phillips and Underhill (1967). Eddy and others (1972) commented that the population appeared to be an isolated northern group. Eddy and Underhill (1974) stated they had not found the weed shiner in any other tributary of the Red River. Collection records of the James Ford Bell Museum of Natural History (written communication, 1992) indicate the species now is found farther north in the Red Lake River. The sauger (Stizostedion canadense) was reported by Eddy and others (1972) as present only in the Canadian portion of the Red River. Eddy and Underhill, just two years later (1974), reported an extended range to the United States portion of the Red River and more recent studies have reported the species from most of the tributaries of the Red River (Naplin and others, 1977; Ryckman, 1981; Enblom, 1982; Renard and others, 1983).

The fish communities of the Red River Basin are not static, but are changing based on the ability of each species to expand its range into new areas when conditions are suitable for survival and reproduction. The Red River Basin is a relatively young system compared to other zoogeographic areas in the country and is still changing.

\section{Recent introductions of fish}

The fish communities of the Red River Basin have also experienced augmentation through the introduction of both indigenous and exotic species through stocking and recent immigration. Within the existing species assemblage, sport fish have been stocked throughout the basin. Eddy and others (1972) and MNDNR records (Paul Glander, MNDNR, written commun., 1994) indicate stocking of largemouth and smallmouth bass (Micropterus salmoides and M. dolomieui), sunfish (Lepomis spp.), crappie (Pomoxis spp.), walleye (Stizostedion vitreum), yellow perch, northern pike (Esox lucius), and channel catfish (Ictalurus punctatus) at various times. Most of the stocking has occurred in the impoundments of the major tributaries to the Red River (Two Rivers and the Roseau River). Sunfish and northern pike have been stocked annually in the Red River at Wahpeton/Breckenridge since 1985. Exotic species such as brown, brook, and rainbow trout (Salmo trutta, Salvelinus fontinalis, and Oncorhynchus mykiss, respectively) also have been stocked in various parts of the basin, primarily headwater streams. In North Dakota, rainbow trout and white bass (Morone chrysops) have been stocked within the Red River Basin (Ryckman, 1981). The North Dakota Game and Fish Department has stocked smallmouth and largemouth bass, muskellunge (Esox masquinongy), bluegills (Lepomis macrochirus), northern pike, walleye, and channel catfish (Peterka, 1978). Stocking of sport species such as bass, crappie, and sunfish has occurred throughout the basin, primarily in ponds and impoundments.

Only one exotic species, the carp, has managed to invade the Red River Basin. Although it is possible that carp originated through accidental bait bucket 
introduction (a non-native species used as bait and then released), it is more probable that the species gained access to the Red River Basin during a spring flood when the headwaters of the Minnesota River and Red River were in contact (Underhill, 1957), and the species migrated upstream in search of shallow spawning areas.

The distribution of species in the major tributaries of the Red River and its mainstem are presented in table 4. These distributions are based on published reports and the records of the James Ford Bell Museum of Natural History (written commun., 1992). Species from small tributaries and headwater streams in the basin are not included due to insufficient data. Therefore, some species (for example, large scale stoneroller (Campostoma oligolepis) and trout) are not listed. In 1992 as part of the USGS Red River of the North NAWQA study, basic reconnaissance sampling was conducted in various rivers and streams in the Red River Basin. This sampling documented a range extension for smallmouth bass into the Buffalo and Clearwater Rivers. The MNDNR had stocked this species initially in the Otter Tail River and the Red Lake River. The dynamic nature of fish populations is evidenced by the documentation of changing ranges and distributions.

\section{Flsherles}

The Red River is internationally known for its trophy channel catfish sport fishery. This fishery is managed by an agreement among the states of Minnesota, North Dakota and the Province of Manitoba, Canada. The agreement established river-wide harvest regulations to manage and protect this exceptional fishery. Although fish greater than 9 kilograms ( 20 pounds) are common, the regulations limit the angler daily catch to five fish, only one greater than 61 centimeters ( 24 inches, about 5 pounds). The international agreement extends to the entire Red River Basin including the tributaries. Research has found the Red River catfish to be highly mobile; it appears that high discharges initiate movements both up and down river (Mike Larson, MNDNR, oral commun., 1994). Tag returns indicated one fish traveled $\mathbf{4 0 0}$ kilometers in 14 days. Red River channel catfish may be the longest lived channel catfish in the United States. Age and growth studies by the MNDNR, have found individuals from 25 to 26 years old. Prior studies of channel catfish have indicated a life expectancy of only 14 years (Carlander, 1977).

The Red River also supports other fisheries. Species sought include walleye, sauger, and northern pike. Other than the large lakes (Upper and Lower Red Lakes and Lake of the Woods), there are very few bodies of water in the northern part of the basin. Aquatic based recreation is limited to the rivers. The Red River and its tributaries support sport fisheries for other species, normally considered rough species, throughout the basin.

\section{Endangered specles}

According to the U. S. Fish and Wildlife Service (Allyn J. Sapa, written commun., 1992; Paul Burke, oral commun., 1992), there are currently no federally listed threatened or endangered fish or aquatic invertebrates in the Red River or its tributaries. North Dakota and Minnesota have established state lists of endangered species (North Dakota Outdoors, 1986; Coffin and Pfannmuller, 1988). Neither state lists aquatic species from the Red River Basin.

\section{Flsh communitles}

The major rivers of the Red River Basin support 75 species of fish (table 4). The species are not evenly distributed between the eastern and western parts of the basin. Excluding the Red River, the western half of the basin (North Dakota) contains 51 species whereas the eastern part of the basin has 71 . Collection records and reports shown on table 4 indicate that the 22 species found only in Minnesota are primarily minnows, suckers, and darters (table 5). Two species, the silver lamprey (Ichthyomyzon unicuspis) and the flathead chub (Platygobio gracilis) have only been found in the mainstem of the Red River. Of the 22 species only found in Minnesota, 17 are found in the Otter Tail River and six of those 17 species (Amia calva, Campostoma anomalum, Notropis anogenus, Hypentelium nigricans, Etheostoma caeruleum, and E. microperca) are recorded only from the Otter Tail River. The Otter Tail River has had 60 species reported, more than any other river or stream in the Red River Basin (table 4).

The Otter Tail River is one of the southernmost Minnesota tributaries to the Red River (collection data from the Rabbit and Mustinka Rivers are incomplete). It would have been one of the first rivers available for pioneering species to occupy as the last glacier retreated. It is also the closest major tributary, other than the Bois de Sioux (which would have been part of the glacial River Warren), to the Mississippi refugia, which was the source of most of the Red River Basin ichthyofauna (Underhill, 1989). Additionally, the Otter Tail River flows through three ecoregions (fig. 5). Each 
Table 4.--Fish distributions in the Red River of the North and its major tributaries

[P, predator; O, omnivore/generalist; I, general insectivore; BI, benthic insectivore; $\mathrm{H}$, herbivore.

Classifications from Karr and others (1986); Plafkin and others (1989); and Eddy and Underhill (1974).]

\begin{tabular}{|c|c|c|c|c|c|c|c|c|c|c|c|c|c|c|c|c|c|c|c|c|c|c|c|c|}
\hline \multirow[b]{2}{*}{ Fish species by Family } & \multirow[b]{2}{*}{ Scientific name } & \multirow[b]{2}{*}{$\begin{array}{c}\text { Native or } \\
\text { introduced } 1\end{array}$} & \multirow[b]{2}{*}{$\begin{array}{c}\text { Trophic } \\
\text { group }\end{array}$} & \multicolumn{11}{|c|}{ North Dakota } & \multirow[b]{2}{*}{ 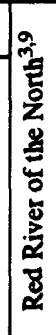 } & \multicolumn{9}{|c|}{ Minnesota } \\
\hline & & & & 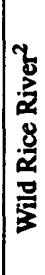 & 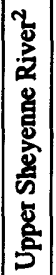 & 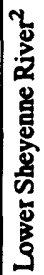 & 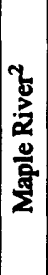 & 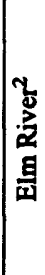 & 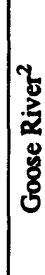 & 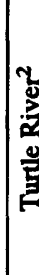 & 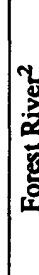 & & & 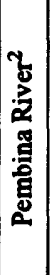 & & 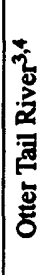 & 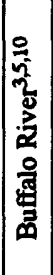 & 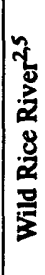 & 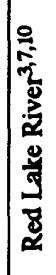 & 总 & 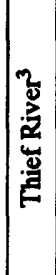 & 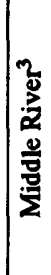 & 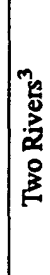 & 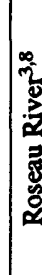 \\
\hline Lampreys & Petromyzontidae & & & & & & & & & & & & & & & & & & & & & & & \\
\hline Chestnut Lamprey & Ichthyomyzon castaneus & Native & $\bar{P}$ & & & & & & & & & & & & $\bar{x}$ & & & $x$ & $x$ & & & & & $\bar{x}$ \\
\hline Silver Lamprey & Ichthyomyzon unicuspis & Native & $\overline{\mathbf{P}}$ & & & & & & & & & & & & $\bar{x}$ & & & & & & & & & \\
\hline Bowfins & Amiidae & & & & & & & & & & & & & & & & & & & & & & & \\
\hline Bowfin & Amia calva & Native & $\bar{P}$ & & & & & & & & & & & & & $x$ & & & & & & & & \\
\hline Mooneyes & Hiodontidae & & & & & & & & & & & & & & & & & & & & & & & \\
\hline Goldeye & Hiodon alosoides & Native & I & & & & & $x$ & & $x$ & & & & & $x$ & $x$ & & $x$ & & & & & & \\
\hline Mooneye & Hiodon tergisus & Native & I & & & $x$ & & & & & & & & $x$ & $x$ & & & $x$ & $x$ & & & & & \\
\hline Mudmilmenows & Umbridae & & & & & & & & & & & & & & & & & & & & & & & \\
\hline Central Mudminnow & Umbra limi & Native & I & & & $x$ & & & & & & & & & & $x$ & $x$ & $x$ & $x$ & & $x$ & $x$ & & $x$ \\
\hline Pikes & Esocidae & & & & & & & & & & & & & & & & & & & & & & & \\
\hline Northern Pike & Esax lucius & Native & $\mathbf{P}$ & $x$ & $x$ & $x$ & $\mathbf{x}$ & $x$ & $x$ & $x$ & $\bar{x}$ & & $\bar{x}$ & $x$ & $\bar{x}$ & $\mathbf{x}$ & $x$ & $x$ & $x$ & $x$ & $x$ & $\bar{x}$ & $\bar{x}$ & $x$ \\
\hline Minnows & Cyprinidae & & & & & & & & & & & & & & & & & & & & & & & \\
\hline Carp & Cyprinus carpio & Introduced & $\mathbf{0}$ & $x$ & & $x$ & $x$ & $x$ & $x$ & $x$ & $\bar{x}$ & & $\bar{x}$ & $x$ & $x$ & $x$ & $x$ & $x$ & $x$ & & & $x$ & $x$ & $x$ \\
\hline Stoneroller & Campostoma anomailum & Native & H & & & & & & & & & & & & & $x$ & & & & & & & & \\
\hline Longnose Dace & Rhinichthys cataractae & Native & BI & & $x$ & $x$ & $x$ & & & & $x$ & & $\bar{x}$ & $x$ & $\bar{x}$ & $x$ & $x$ & $x$ & $x$ & $x$ & & & & $x$ \\
\hline Blacknose Dace & Rhinichthys atratulus & Native & BI & & $x$ & $x$ & $x$ & & $x$ & $x$ & $x$ & & $\bar{x}$ & $x$ & $x$ & $x$ & & $x$ & $x$ & $x$ & & $x$ & $x$ & $x$ \\
\hline Creek Chub & Semotilus atromaculatus & Native & I & $x$ & $x$ & $x$ & $\sqrt{x}$ & $x$ & $x$ & $x$ & $\bar{x}$ & & $\bar{x}$ & $x$ & $x$ & $x$ & $x$ & $x$ & & & & $x$ & $x$ & $\bar{x}$ \\
\hline Pearl Dace & Margariscus margarita & Native & I & & & & & & & & & & & & & & & & $x$ & & $x$ & $x$ & & $\bar{x}$ \\
\hline Flathead Chub & Platygobio gracilis & Native & I & & & & & & & & & & & & $\bar{x}$ & & & & & & & & & \\
\hline Silver Chub & Macrhybopsis storeriana & Native & BI & & & $x$ & & & & $\bar{x}$ & & & & $x$ & $x$ & & & & $x$ & & & & $\bar{x}$ & \\
\hline Hornyhead Chub & Nocomis biguttatus & Native & $\mathbf{I}$ & & & & & & & & & & & & & $x$ & $x$ & $x$ & $x$ & $x$ & & & & \\
\hline Northern Redbelly Dace & Phoxinus eas & Native & I & & & $x$ & & & $x$ & & & & $\bar{x}$ & $x$ & & $x$ & & $x$ & $x$ & & $x$ & $x$ & & $x$ \\
\hline Finescale Dace & Phoxinus neogaeus & Native & I & & & & & & & & & & & & & $x$ & & & $x$ & & $\bar{x}$ & $x$ & & $\bar{x}$ \\
\hline Golden Shiner & Notemigonus crysoleucas & Native & 0 & & $x$ & $x$ & & & & & & & & & $x$ & $\mathbf{x}$ & & $x$ & $x$ & & & & & \\
\hline Fathead Minnow & Pimephales promelas & Native & o & $x$ & $x$ & $x$ & $x$ & $x$ & $x$ & $x$ & $\bar{x}$ & & $\bar{x}$ & $x$ & $x$ & $x$ & $x$ & $x$ & $x$ & $x$ & $x$ & $x$ & $x$ & $\bar{x}$ \\
\hline Bluntnose Minnow & Pimephales notatus & Native & 0 & & & $x$ & $x$ & & $x$ & & $x$ & & $\bar{x}$ & & & $x$ & $x$ & & $x$ & & & & & \\
\hline Pugnose Shiner & Notropis anogenus & Native & I & & & & & & & & & & & & & $x$ & & & & & & & & \\
\hline Brassy Minnow & Hybognathus hankinsoni & Native & 0 & & & $\sqrt{x}$ & $x$ & & & & & & & & & $x$ & & & & & & $x$ & & \\
\hline Spottail Shiner & Notropis hudsonius & Native & I & & $x$ & $x$ & & & & & & & & & & $x$ & $x$ & & $x$ & & & & & \\
\hline Common Shiner & Luxilus cornutus & Native & I & & $x$ & $x$ & $x$ & & $x$ & $x$ & $\bar{x}$ & & $x$ & $x$ & $x$ & $x$ & $x$ & $x$ & $x$ & $x$ & $x$ & $x$ & $x$ & $x$ \\
\hline Spotfin Shiner & Cyprinella spiloptera & Native & I & & & $x$ & & & & & & & & & $x$ & $x$ & & $x$ & & & & & & \\
\hline Emerald Shiner & Notropis atherinoides & Native & I & & & $x$ & & & & & & & & $\bar{x}$ & $x$ & $x$ & & & $\bar{x}$ & & & & & \\
\hline Bigmouth Shiner & Notropis dorsalis & Native & BI & & & $x$ & $x$ & & $\bar{x}$ & $x$ & & & $x$ & $x$ & & $x$ & $x$ & $x$ & $x$ & $x$ & $x$ & & & $\bar{x}$ \\
\hline River Shiner & Notropis blennius & Native & BI & & & & & & & & $\bar{x}$ & & $x$ & $x$ & $x$ & & $x$ & & & & & & & \\
\hline Rosyface Shiner & Notropis rubellus & Native & I & & & & & & & & & & & & & & & $x$ & $x$ & $x$ & & & & \\
\hline Blackchin Shiner & Notropis heterodon & Native & I & & & & & & & & & & & & & $x$ & $x$ & $x$ & $\bar{x}$ & & & & & \\
\hline Blacknose Shiner & Notropis heterolepis & Native & $\mathbf{I}$ & & & & & & & & & & & & & $x$ & $x$ & $x$ & & & & & & $x$ \\
\hline Mimic Shiner & Notropis volucellus & Native & BI & & & & & & & & & & & & & $x$ & $x$ & $x$ & & & & & & \\
\hline Weed Shiner & Notropis texanus & Native & I & & & & & & & & & & & & & $x$ & & & $x$ & & & & & \\
\hline Sand Shiner & Notropis stramineus & Native & BI & & $x$ & $x$ & $x$ & & $x$ & & $x$ & & & $\bar{x}$ & $x$ & $x$ & & $x$ & $x$ & $x$ & & & $x$ & \\
\hline Suckers & Catostomidae & & & & & & & & & & & & & & & & & & & & & & & \\
\hline Bigmouth Buffalo & Ictiobus cyprinellus & Native & I & $x$ & & $x$ & $x$ & & & & $x$ & & $x$ & $x$ & $x$ & $x$ & & & & & & & $\bar{x}$ & \\
\hline Quillback & Carpiodes cyprinus & Native & 0 & & & $x$ & $x$ & & & & $x$ & & $\bar{x}$ & $x$ & $x$ & $x$ & & $x$ & $x$ & & $x$ & & $x$ & \\
\hline Silver Redhorse & Moxostoma anisurum & Native & BI & & & & & & & & & & & & $x$ & $x$ & & $x$ & $x$ & $x$ & & & & $x$ \\
\hline Greater Redhorse & Moxostoma valenciennesi & Native & BI & & & $x$ & & & & & & & & & $x$ & $x$ & & & & & & & & \\
\hline Shorthead Redhorse & Moxostoma macrolepidotum & Native & BI & & & $x$ & & $x$ & $x$ & & & & $x$ & $x$ & $|x|$ & $|x|$ & $x$ & $x$ & $x$ & $x$ & & \begin{tabular}{|l|}
$x$ \\
\end{tabular} & $x$ & $\bar{x}$ \\
\hline Golden Redhorse & Moxostoma erythrurum & Native & $\overline{\text { BI }}$ & & & & & & & & & & & & $x$ & $x$ & $x$ & $x$ & $x$ & $x$ & & & & \\
\hline
\end{tabular}


Table 4.--Fish distributions in the Red River of the North and its major tributaries--Continued

\begin{tabular}{|c|c|c|c|c|c|c|c|c|c|c|c|c|c|c|c|c|c|c|c|c|c|c|c|}
\hline \multirow[b]{2}{*}{ Fish species by Family } & \multirow[b]{2}{*}{ Scientific name } & \multirow[b]{2}{*}{$\begin{array}{c}\text { Native or } \\
\text { introduced }\end{array}$} & \multirow[b]{2}{*}{$\begin{array}{c}\text { Trophic } \\
\text { group }\end{array}$} & \multicolumn{10}{|c|}{ North Dakota } & \multirow[b]{2}{*}{ 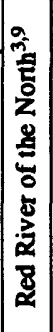 } & \multicolumn{9}{|c|}{ Minnesota } \\
\hline & & & & 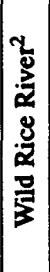 & 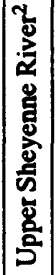 & 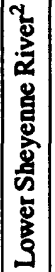 & 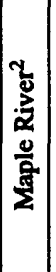 & 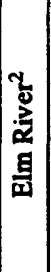 & 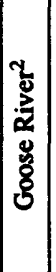 & 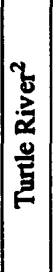 & 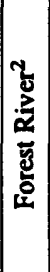 & 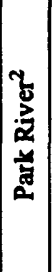 & 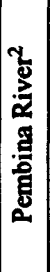 & & 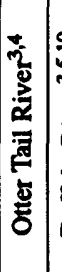 & 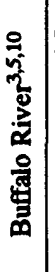 & 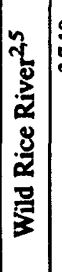 & 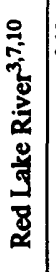 & 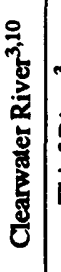 & 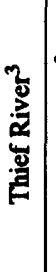 & 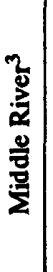 & 隽 & 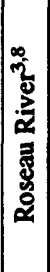 \\
\hline White Sucker & Catostomus commersoni & Native & BI & $x$ & $\bar{x}$ & $\bar{x}$ & $x$ & $x$ & $x$ & $\bar{x}$ & $x$ & $x$ & $\mathrm{x}$ & $\mathrm{x}$ & $x$ & $x$ & $\bar{x}$ & $x$ & $x$ & $x$ & $x$ & $x$ & $x$ \\
\hline Northern Hogsucker & Hypentelium nigricans & Native & BI & & & & & & & & & & & & $\mathrm{x}$ & & & & & & & & \\
\hline Longnose Sucker & Catostomus catostomus & Native & BI & & & & & & & & & & & & & & & & $x$ & & & & $\bar{x}$ \\
\hline Cattish & Ictaluridae & & & & & & & & & & & & & & & & & & & & & & \\
\hline Channel Catfish & Ictalurus punctatus & Native & $\bar{P}$ & & & $x$ & $x$ & & $\mathrm{x}$ & $\bar{x}$ & $x$ & $\mathbf{x}$ & $x$ & $x$ & $x$ & $\mathbf{x}$ & $x$ & $x$ & & & & & \\
\hline Brown Bullhead & Ameiurus nebulosus & Native & I & & $\bar{x}$ & & & $x$ & $x$ & $x$ & $x$ & $x$ & $x$ & & $\mathrm{x}$ & $x$ & $\bar{x}$ & $x$ & & & & $\bar{x}$ & \\
\hline Black Bullhead & Ameiurus melas & Native & $\mathbf{I}$ & $x$ & $x$ & $x$ & $x$ & $x$ & $x$ & $x$ & $x$ & $x$ & $x$ & $x$ & $x$ & $\mathbf{x}$ & $x$ & $x$ & & & $x$ & $x$ & \\
\hline Yellow Bullhead & Ameiurus natalis & Native & I & & & & & & & & & & & & $x$ & $x$ & & & & & & & \\
\hline Stonecat & Noturus flavus & Native & I & $x$ & & $x$ & & $x$ & & & & & & $x$ & & & $x$ & & & & $x$ & & \\
\hline Tadpole Madtom & Noturus gyrinus & Native & I & & $x$ & $x$ & $x$ & & $x$ & $x$ & $\mathrm{x}$ & & & $x$ & $x$ & $x$ & $x$ & $x$ & $x$ & & & & $x$ \\
\hline Trout-Perch & Percopsidae & & & & & & & & & & & & & & & & & & & & & & \\
\hline Trout-Perch & Percopsis omiscomaycus & Native & I & $x$ & $x$ & $\bar{x}$ & & & $x$ & $x$ & $\bar{x}$ & $x$ & $x$ & $x$ & $x$ & $x$ & $x$ & $x$ & & & & & $x$ \\
\hline Cods & Gadidae & & & & & & & & & & & & & & & & & & & & & & \\
\hline Burbot & Lota lota & Native & $\mathbf{P}$ & & & & & & & & & & & $x$ & $x$ & & $x$ & $x$ & & & & & $x$ \\
\hline Killifishes & Cyprinodontidae & & & & & & & & & & & & & & & & & & & & & & \\
\hline Banded Killifish & Fundulus diaphanus & Native & $I$ & & & & & & & $x$ & & & & & $x$ & $x$ & & & & & & & \\
\hline Sticklebacks & Gasterosteidae & & & & & & & & & & & & & & & & & & & & & & \\
\hline Brook Stickleback & Culaea inconstans & Native & I & $x$ & $\bar{x}$ & $\bar{x}$ & $x$ & $x$ & $x$ & $x$ & $\bar{x}$ & $x$ & $x$ & $\bar{x}$ & $x$ & $x$ & $x$ & $x$ & $x$ & $x$ & $x$ & & $x$ \\
\hline Drums & Scianidae & & & & & & & & & & & & & & & & & & & & & & 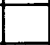 \\
\hline Freshwater Drum & Aplodinotus grunniens & Native & $I$ & $\mathbf{x}$ & & $x$ & $\mathbf{x}$ & $\mathbf{x}$ & & $x$ & $x$ & & & $x$ & $x$ & & $x$ & $x$ & & & & $x$ & $x$ \\
\hline Temperate Basses & Percichthyidae & & & & & & & & & & & & & & & & & & & & & & \\
\hline White Bass & Morone chrysops & Introduced & $\overline{\mathbf{P}}$ & & $x$ & $x$ & & & & & & & & $x$ & $x$ & & & & & & & & \\
\hline Bass and Sunfishes & Centrarchidae & & & & & & & & & & & & & & & & & & & & & & \\
\hline Largemouth Bass & Micropterus salmoides & Native & $\overline{\mathbf{P}}$ & & $x$ & & & & & & & $x$ & & & $x$ & $x$ & & $x$ & & & & & \\
\hline Smallmouth Bass & Micropterus dolomieu & Native & $\mathbf{P}$ & & $x$ & $x$ & & & & & & & & & & $x$ & & & $x$ & & & & \\
\hline Green Sunfish & Lepomis cyanellus & Native & I & & $\bar{x}$ & $x$ & $x$ & & & & & & & $x$ & $x$ & $x$ & & & & & & & \\
\hline Orangespotted Sunfish & Lepomis humilis & Native & I & & $x$ & $x$ & & & & & & & & & & & & & & & & & \\
\hline Bluegill & Lepomis macrochirus & Native & I & $x$ & $x$ & $x$ & & & & & & & & & $x$ & $x$ & & & & & & & \\
\hline Pumpkinseed & Lepomis gibbosus & Native & I & & $x$ & $x$ & & $x$ & & & & $x$ & & & $x$ & $x$ & $x$ & & & & & & \\
\hline Rock Bass & Ambloplites rupestris & Native & $\mathbf{P}$ & $\mathrm{x}$ & & $\mathbf{x}$ & & & & 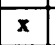 & $x$ & & & $x$ & $x$ & $x$ & $x$ & $\mathbf{x}$ & $x$ & & & & $x$ \\
\hline Black Crappie & Pomoxis nigromaculatus & Native & $\mathbf{P}$ & & $\mathbf{x}$ & $x$ & $x$ & $x$ & $x$ & & $x$ & $x$ & $x$ & $x$ & $x$ & $x$ & & $x$ & & & & & \\
\hline White Crappie & Pomoxis annularis & Introduced & $\mathbf{P}$ & & $x$ & $x$ & $\mathbf{x}$ & & & & & $x$ & & $x$ & & & & & & & & & \\
\hline Perches & Percidae & & & & & & & & & & & & & & & & & & & & & & \\
\hline Yellow Perch & Perca flavescens & Native & $\mathbf{P}$ & $x$ & $x$ & $x$ & & $x$ & $x$ & $\mathbf{x}$ & $x$ & $x$ & $\mathbf{x}$ & $x$ & $x$ & $x$ & $x$ & $x$ & & & & $\mathrm{x}$ & \\
\hline Walleye & Stizostedion vitreum & Native & $\mathbf{P}$ & $x$ & $x$ & $x$ & & $x$ & $x$ & $x$ & $x$ & $x$ & $x$ & $x$ & $x$ & $x$ & $x$ & $x$ & $\bar{x}$ & & & $x$ & $x$ \\
\hline Sauger & Stizostedion canadense & Native & $\mathbf{P}$ & & & $x$ & & & $x$ & $\mathbf{x}$ & $x$ & $x$ & $x$ & $x$ & & & $x$ & $x$ & & & & $x$ & $x$ \\
\hline Logperch & Percina caprodes & Native & BI & & & & & & & & & & & $x$ & $x$ & & & $x$ & & & & & \\
\hline Blackside Darter & Percina maculata & Native & BI & & $x$ & $x$ & $x$ & & $x$ & $x$ & $x$ & $x$ & $x$ & $x$ & $x$ & $x$ & $x$ & $x$ & $x$ & $x$ & $x$ & $x$ & $x$ \\
\hline River Darter & Percina shumardi & Native & BI & & & & & & & & & & & & & $x$ & & $x$ & & & & & \\
\hline Johnny Darter & Echeostoma nigrum & Native & BI & & $x$ & $x$ & $x$ & $x$ & $x$ & $x$ & $x$ & $x$ & $x$ & & $x$ & $x$ & $x$ & $x$ & $x$ & $x$ & $x$ & $x$ & $x$ \\
\hline Iowa Darter & Etheostoma exile & Native & BI & & $x$ & $x$ & $x$ & & & & & & & & $x$ & & $x$ & & & $x$ & & & $x$ \\
\hline Rainbow Darter & Etheostoma caeruleum & Native & BI & & & & & & & & & & & & $x$ & & & & & & & & \\
\hline Least Darter & Etheostoma microperca & Native & BI & & & & & & & & & & & & $\bar{x}$ & & & & & & & & \\
\hline Total species & & & & 15 & \begin{tabular}{|l|}
29 \\
\end{tabular} & 46 & 25 & 17 & 24 & 24 & 27 & 29 & 29 & 43 & \begin{tabular}{l|l}
60 & 3 \\
\end{tabular} & 38 & 43 & 46 & \begin{tabular}{l|l}
21 & 1 \\
\end{tabular} & \begin{tabular}{l|l}
14 & 1 \\
\end{tabular} & 18 & 20 & 29 \\
\hline & $\begin{array}{l}1 \text { Eddy and Underh } \\
2 \text { Ryckman (1981) } \\
3 \text { James Ford Bell M } \\
{ }^{4} \text { Hanson and other } \\
{ }^{5} \text { Reedstrom (1967) }\end{array}$ & $\begin{array}{l}\text { 1974) } \\
\text { um of Natu }\end{array}$ & 15 to & & & & & & & & $\begin{array}{l}\text { enar } \\
\text { inblo } \\
\text { lenar } \\
\text { U.S. }\end{array}$ & $\begin{array}{l}\text { rd an } \\
\text { m (1 } \\
\text { rd an } \\
\text { Ceol }\end{array}$ & & & $\begin{array}{l}(1977) \\
(1983)\end{array}$ & & & & & & & & \\
\hline
\end{tabular}


Table 5.--Fishes with geographically distinct distributions in the Red River of the North Basin

\begin{tabular}{|c|c|c|c|}
\hline \multicolumn{2}{|c|}{ Species by family } & \multirow{2}{*}{$\begin{array}{c}\text { Minnesota } \\
\text { tributaries only }\end{array}$} & \multirow{2}{*}{$\begin{array}{c}\text { Red River } \\
\text { mainstream only }\end{array}$} \\
\hline Common name & Scientific name & & \\
\hline Lampreys & Petromyzontidae & & \\
\hline Chestnut Lamprey & Ichthyomyzon castaneus & $\mathbf{X}$ & \\
\hline Silver Lamprey & Ichthyomyzon unicuspis & & $\mathbf{X}$ \\
\hline Bowfins & Amiidae & & \\
\hline Bowfin & Amia calva & $\mathbf{X}$ & \\
\hline Minnows & Cyprinidae & & \\
\hline Stoneroller & Campostoma anomalum & $\mathbf{X}$ & \\
\hline Pearl Dace & Margariscus margarita & $\mathbf{X}$ & \\
\hline Flathead Chub & Platygobio gracilis & & $\mathbf{x}$ \\
\hline Hornyhead Chub & Nocomis biguttatus & $\mathbf{x}$ & \\
\hline Finescale Dace & Phoxinus neogaeus & $\mathbf{x}$ & \\
\hline Pugnose Shiner & Notropis anogenus & $\mathbf{X}$ & \\
\hline Roseyface Shiner & Notropis rubellus & $\mathbf{X}$ & \\
\hline Blackchin Shiner & Notropis heterodon & $\mathbf{X}$ & \\
\hline Blacknose Shiner & Notropis heterolepis & $\mathbf{X}$ & \\
\hline Mimic Shiner & Notropis volucellus & $\mathbf{X}$ & \\
\hline Weed Shiner & Notropis texanus & $\mathbf{X}$ & \\
\hline Suckers & Catostomidae & & \\
\hline Silver Redhorse & Moxostoma anisurum & $\mathbf{X}$ & \\
\hline Golden Redhorse & Moxostoma erythrurum & $\mathbf{X}$ & \\
\hline Longnose Sucker & Catostomus catostomus & $\mathbf{X}$ & \\
\hline Northern Hogsucker & Hypentelium nigricans & $\mathbf{X}$ & \\
\hline Catfishes & Ictaluridae & & \\
\hline Yellow Bullhead & Ameiurus natalis & $\mathbf{x}$ & \\
\hline Cods & Gadidae & & \\
\hline Burbot & Lota lota & $\mathbf{X}$ & \\
\hline Perches & Percidae & & \\
\hline Logperch & Percina caprodes & $\mathbf{X}$ & \\
\hline River Darter & Percina shumardi & $\mathbf{X}$ & \\
\hline Rainbow Darter & Etheostoma caeruleum & $\mathbf{X}$ & \\
\hline Least Darter & Etheostoma microperca & $\mathbf{X}$ & \\
\hline
\end{tabular}

ecoregion provides conditions that are ecologically different and therefore has the potential to support different biota. A comparison of species richness (number of species) and the number of ecoregions that a river flows through indicates that there is a significant difference (analysis of variance (ANOVA), statistical significance level $(P)<0.005)$, between the number of species found in rivers that flow through one, two, or three ecoregions (fig. 6). The Otter Tail River has its headwaters in the Northern Lakes and Forests ecoregion where it flows through many small lakes. It then flows through the North Central Hardwood Forest ecoregion, an area of higher gradient, before entering the Red River Valley ecoregion and its confluence with the Red River. Many of the 22 species found only in the Minnesota portion of the basin are found in the eastern two ecoregions and reflect the combination of lotic and lentic environments unique to this area of the Red River Basin (Eddy and Underhill, 1974). 


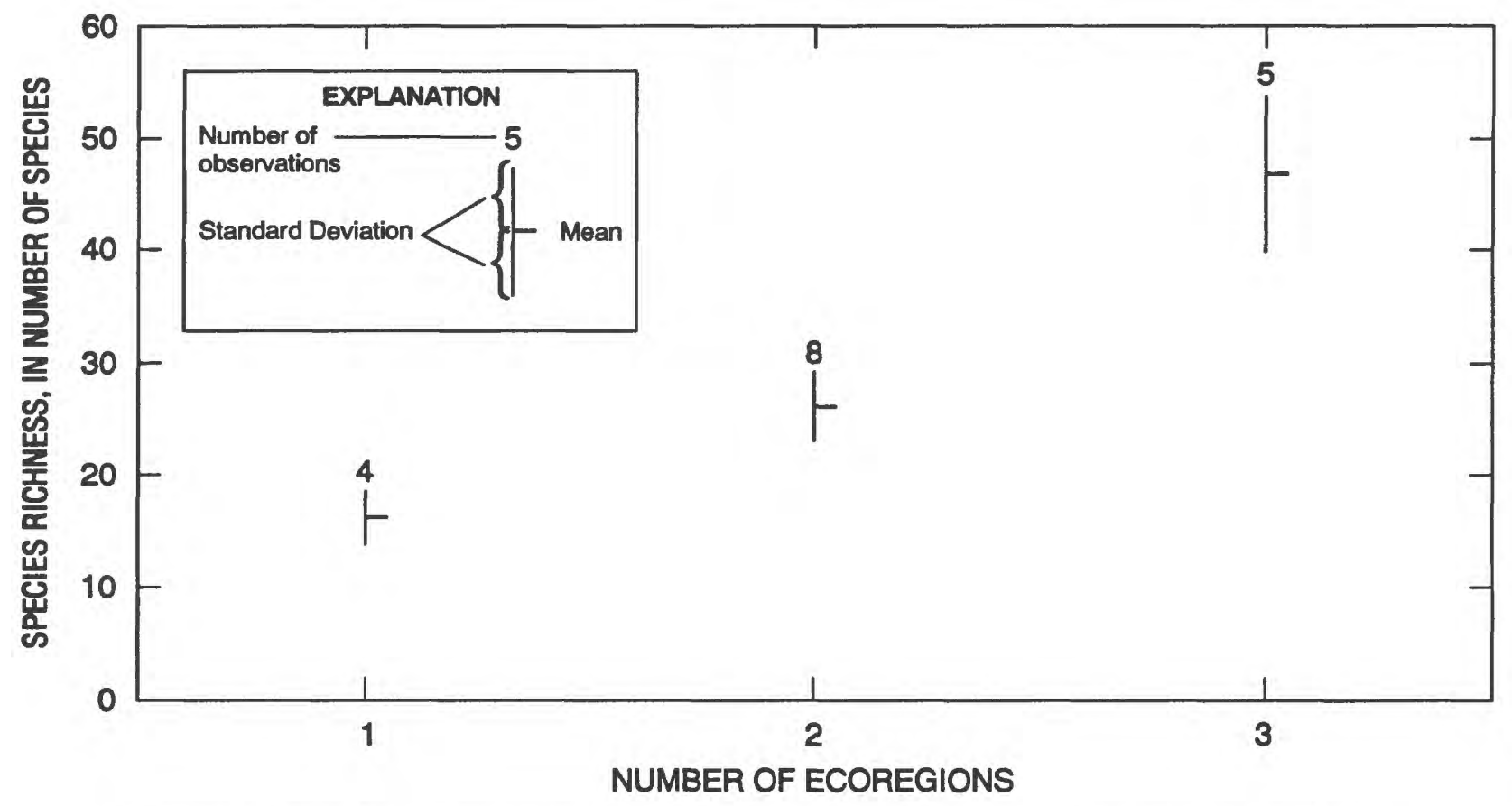

Figure 6. Species richness of rlvers that flow through one, two, or three ecoregions, Red River of the North Basin.

The addition of species to the ichthyofauna of a stream as the stream increases in size from its headwaters through its mid-reaches and to its mainstem has been documented. This relation has been expressed in terms of some measure of stream size, usually drainage basin area or stream order (Shelford, 1911; Harrel and others, 1967; Sheldon, 1968; Goldstein, 1981) but has not been expressed in relation to ecoregions. Within the Red River Basin there is a tendency for the number of species to increase with stream size. Species richness was significantly correlated with drainage basin area (fig. 7). However, when the trend of increasing species is examined with both drainage basin size and the number of ecoregions the river flows through, it appears that both factors are involved and autocorrelated. For example, as rivers increase in drainage basin area, there is a greater likelihood that a river will flow through more than one ecoregion (fig. 8).

Of the $\mathbf{7 5}$ fish species found in the major tributaries of the Red River, only three-the white sucker (Catostomus commersoni), the fathead minnow (Pimephales promelas), and the northern pike-are common to all rivers. Additionally, there are another nine species found in at least $\mathbf{8 0}$ percent of the major tributaries: carp, creek chub (Semotilus atromaculatus), blacknose dace (Rhinichthys atratulus) common shiner
(Luxilus cornutus), black bullhead (Ameiurus melas), brook stickleback (Culaea inconstans), walleye, blackside darter (Percina maculata), and johnny darter (Etheostoma nigrum) (table 4).

The fish communities of the major rivers in the Red River Basin were analyzed for similarity. Jaccard's coefficient of similarity was calculated for each pair of rivers in a river-by-river matrix. The results (coefficients) were used to provide input for a cluster analysis (SAS, 1989). The cluster-analysis procedure mathematically groups the rivers with the most similar ichthyofauna. At each step, the most similar groups are joined until all combinations have been examined. The similarity coefficients are used to measure the degree of commonality, expressed as relative distance, between two groups. Three procedures were run; single linkage, average linkage, and complete linkage. All three procedures produced similar results so only the results of the average linkage procedure are presented. Results of the cluster analysis are shown in figure 9.

The first group of similar rivers consisted of the Wild Rice and Elm Rivers in North Dakota. Both flow through the southwestern portion of the Red River Valley ecoregion. While the Wild Rice River has its headwaters in the Northern Glaciated Plains ecoregion, most of the river in that ecoregion is intermittent. These 


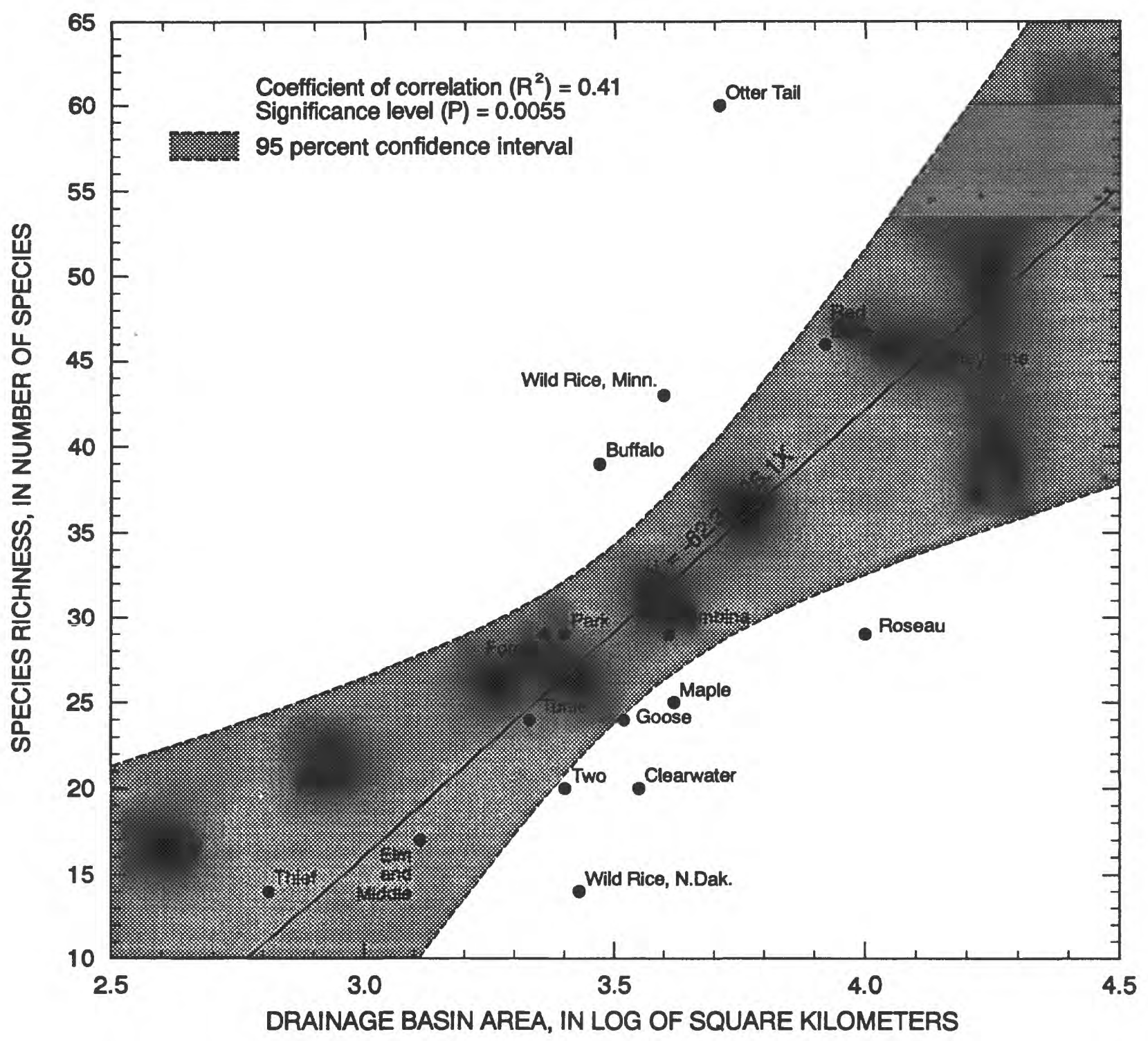

Figure 7. Relation of species richness and drainage basin area for streams in the Red River of the North Basin.

rivers contain fish communities with relatively few species ( 15 and 17, respectively), and contain eight and nine species, respectively, of the twelve species of fish found in $\mathbf{8 0}$ to $\mathbf{1 0 0}$ percent of the major rivers. Darters were conspicuously absent in the Wild Rice River and only the johnny darter was found in the Elm River.

The second group of similar rivers contained rivers that flow through two or three ecoregions as well as the Red River. All these rivers have significantly more species than the other major tributaries to the Red River and the high species richness results in similarity.
The third group of similar rivers includes all the other rivers in North Dakota that flow through two ecoregions (the Northern Glaciated Plains and the western part of the Red River Valley). The only river in this group that does not meet these criteria is the Two Rivers in Minnesota. The Two Rivers contains all of the twelve most common species. The other eight species are sufficiently similar to the North Dakota river species assemblages that the Two Rivers was included in this grouping.

The last two groups contain two rivers each. The Clearwater and Roseau Rivers were grouped together. 


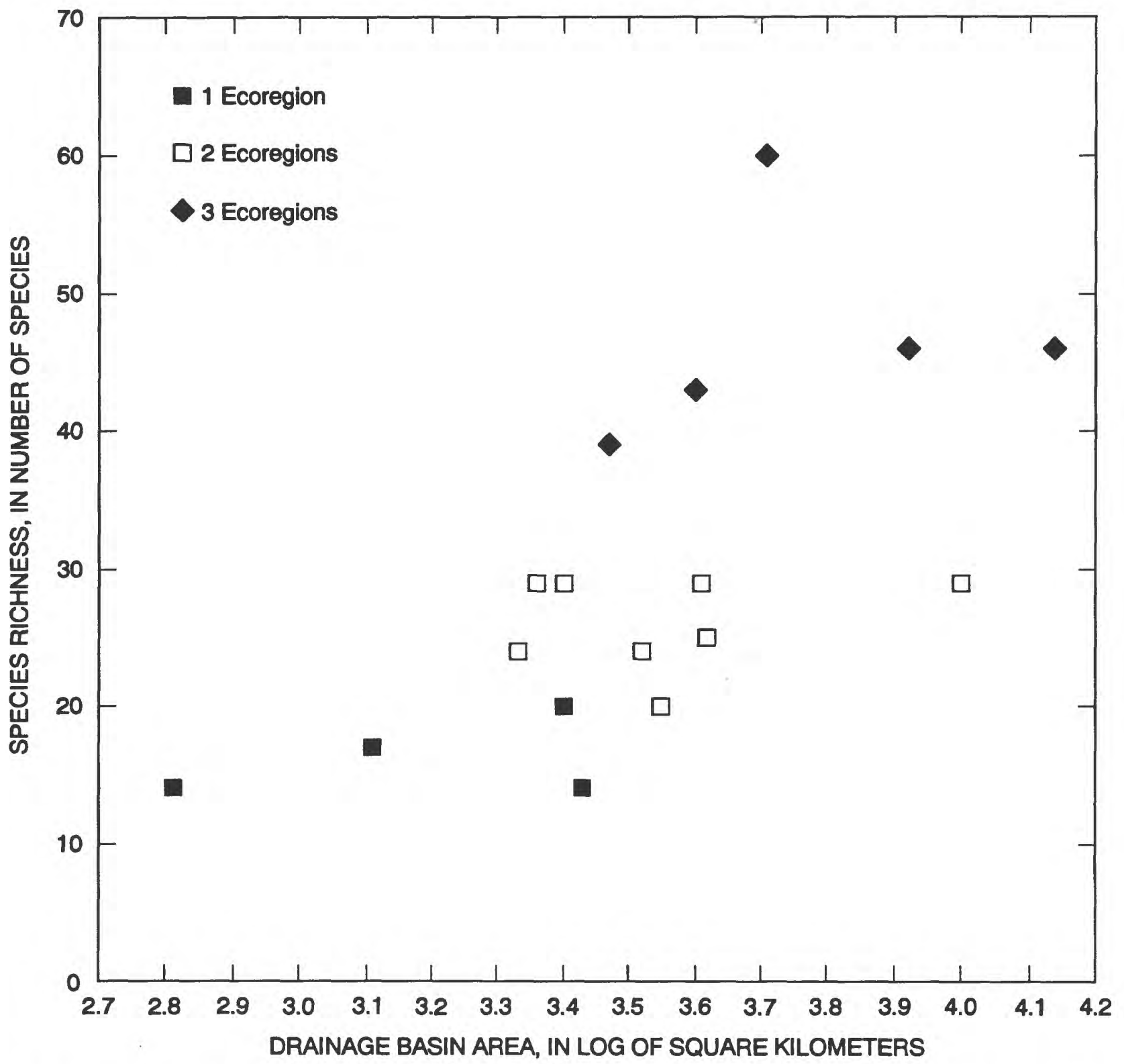

Figure 8. Relation of specles richness, dralnage basin area, and the number of ecoreglons a river flows through in the Red Rlver of the North Basin.

Both rivers have tributaries in the Northern Minnesota Wetlands ecoregion and are somewhat similar to the prior two groups. The last group of two rivers contains the Thief and Middle Rivers. The headwaters of both these rivers are adjacent in the wetland area near Thief Lake. Both have few species of fish (14 and 18, respectively) compared to the other rivers and so they form a group like the North Dakota Wild Rice and Elm Rivers, which also contain comparatively few species.
These two groups of rivers have species assemblages which are the least related to the other groups.

Although certain features of a drainage area help to explain commonality of the rivers within the five river groups identified by the cluster analysis, they do not address the species assemblages by which the clusters were defined, nor identify the differences in the species assemblages among the river groups. All river groups were compared by trophic composition. The percentage of species in each of four trophic groups (predators, 


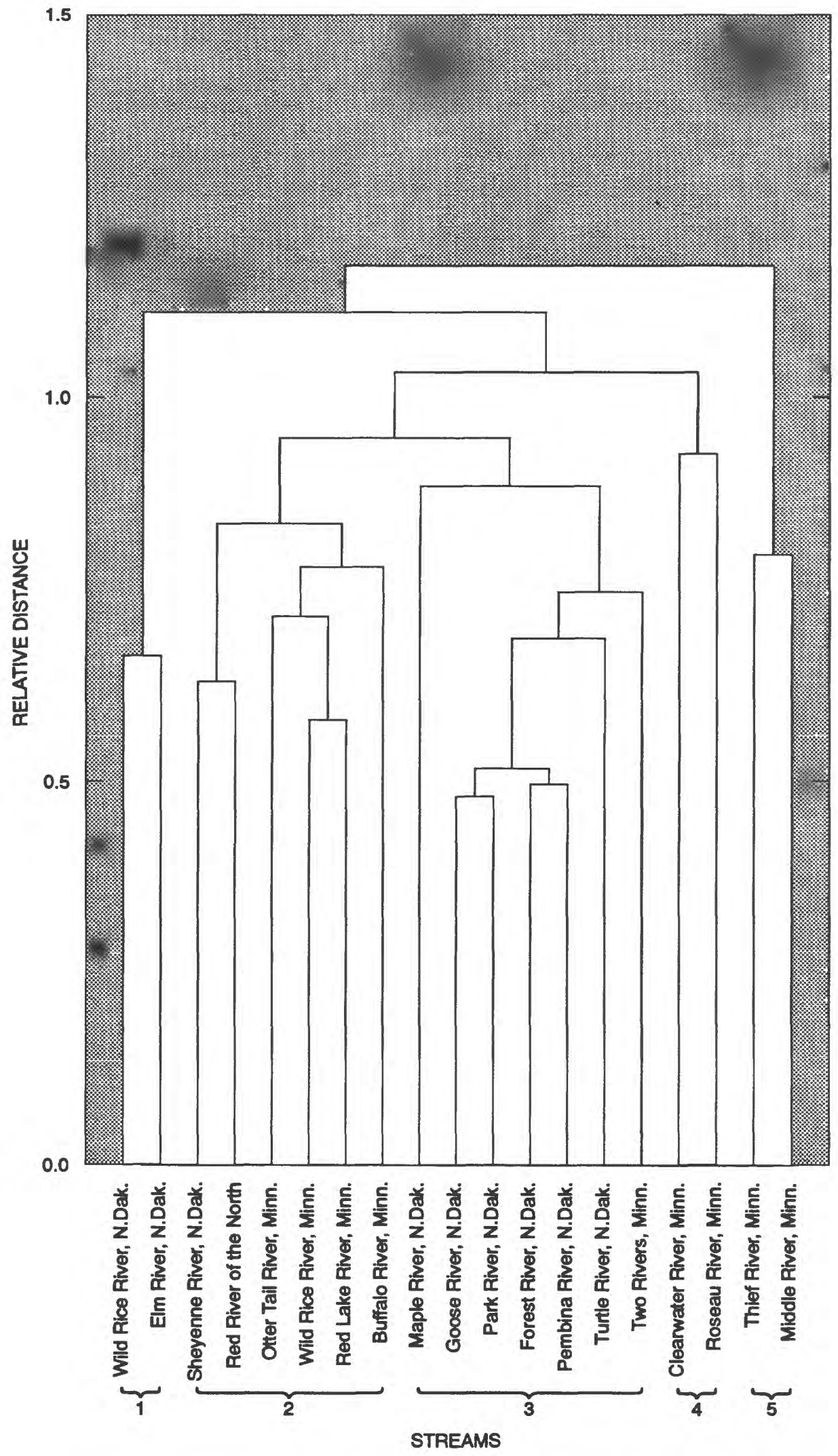

Figure 9. Average linkage cluster analysis for species composition of streams in the Red River of the North Basin. 
omnivores/generalists, benthic insectivores, and general insectivores) (table 4) were compared among the river groups by analysis of variance to determine if there was a difference among the river groups and then, by Tukey's Studentized Range method, to determine which river groups differed at a significance level of 0.05 (SAS, 1989). Classification of species in trophic groups was based on Scott and Crossman (1973), Eddy and Underhill (1974), Karr and others (1986), and Plafkin and others (1989). Herbivores were excluded from the analysis because only one species of herbivore, the stoneroller, was reported from only one river, the Otter Tail River.

The percent of species classified as predators (top carnivores/piscivores) differed among the five river groups (ANOVA, $P<0.003$ ). Only river group five, the Thief and Middle Rivers, was different from the other groups (fig. 10). This group of rivers had significantly fewer predator species than the other river groups (means of 7 vs. 20 percent, respectively) and contained no bass or sunfish.

The percentage of species in the omnivores/ generalists group differed among the river cluster groups (ANOVA, $P<0.0002$ ). Comparison of the river groups indicated that groups 1,3 , and 5 were similar, groups 2 and 5 were similar, as were groups 2 and 4 (fig. 10). The percentage of species that were omnivor es/generalists decreased in these groups (means from 12 percent to 25 percent).

The percentage of species which are benthic insectivores differed among the river cluster groups (ANOVA, $P<0.0008$ ). River cluster groups 2 and 3 were similar and groups 3,4 , and 5 were similar (fig. 10). River cluster group 1 had the lowest percentage of species which are classified as benthic insectivores (mean of 6 percent), groups 2 , and 3 intermediate (mean of 22 percent), and groups 4 and 5 had the largest percentage of species (mean of 33 percent).

The other trophic group, general insectivores, also provided discriminatory ability for distinguishing the river groups. The percentage of species in this trophic group was different among the river groups (ANOVA, $P$ $<0.002$ ). River groups 1, 2, and 5 each contained similar percentages of general insectivore species (fig. 10) (mean of 44 percent), and groups 3 and 4 were similar with fewer insectivore species.

Based on the proportion of species among the various trophic groups, there is sufficient evidence to distinguish the river groups. No two river groups contained the same proportions of species in the four trophic groups, although there were similarities within a trophic group among some river groups.
Another approach to defining the differences among the river groups is to examine the proportion of species within each of the four largest taxonomic groups: minnows (Cyprinidae); suckers (Catostomidae); and bass and sunfish; and the subfamily of darters (Etheostomitinae). The percentage of species in each taxonomic group was compared among river groups by analysis of variance and appropriate comparisons.

Analysis of variance did not support differences among river groups based on the percentage of species in either the sucker or bass and sunfish families. The proportion of total species within the minnow family was different among river groups (ANOVA, $\mathrm{P}<0.0002$ ). Comparisons between the river groups indicated that group 1 was different from all other groups, groups 2, 3, and 4 were similar, and groups 4 and 5 were similar (fig. 11). The proportion of species in the subfamily of darters differed among the river groups (ANOVA, $P$ $<0.001$ ). Groups 1 and 2 were similar, groups 2,3 , and 4 were similar, and groups 4 and 5 were similar (fig. 11).

The comparisons presented in figures 10 and 11 indicate the relative amounts of commonality of each river group based on the percent of total species in various trophic and taxonomic groups. River groups 2 , 3 , and 4 had the most commonality while groups 1 and 5 had the least. The relative frequency of commonality reflects the original separation by cluster analysis (fig. 9) which indicated groups 2,3 , and 4 were more closely related while groups 1 and 5 were less closely related based on species richness and composition.

The number of species found in Red River Basin rivers is related to stream size as measured by watershed area. Although species richness is significantly correlated with watershed area (fig. 7), the amount of variance explained by the regression is relatively low (41 percent). Assuming the species richness-watershed area relation is real and significant, which has been determined for other smaller basins (Harrel and others, 1967; Sheldon, 1968; Goldstein, 1981), then certain of the rivers have species richness values which can be considered outliers, or points located some distance (outside the 95 percent confidence limits) from the regression line. Some factors exist to affect the species richness-watershed area relation in those rivers. Those rivers that appear to contain fewer species than expected from the regression are the Roseau, Maple, Clearwater, and Wild Rice (North Dakota) Rivers. The Otter Tail, Wild Rice (Minnesota), and the Buffalo Rivers appear to contain more species than expected (fig. 7). All the other rivers contain approximately the number of species that would be predicted from differences associated with the 


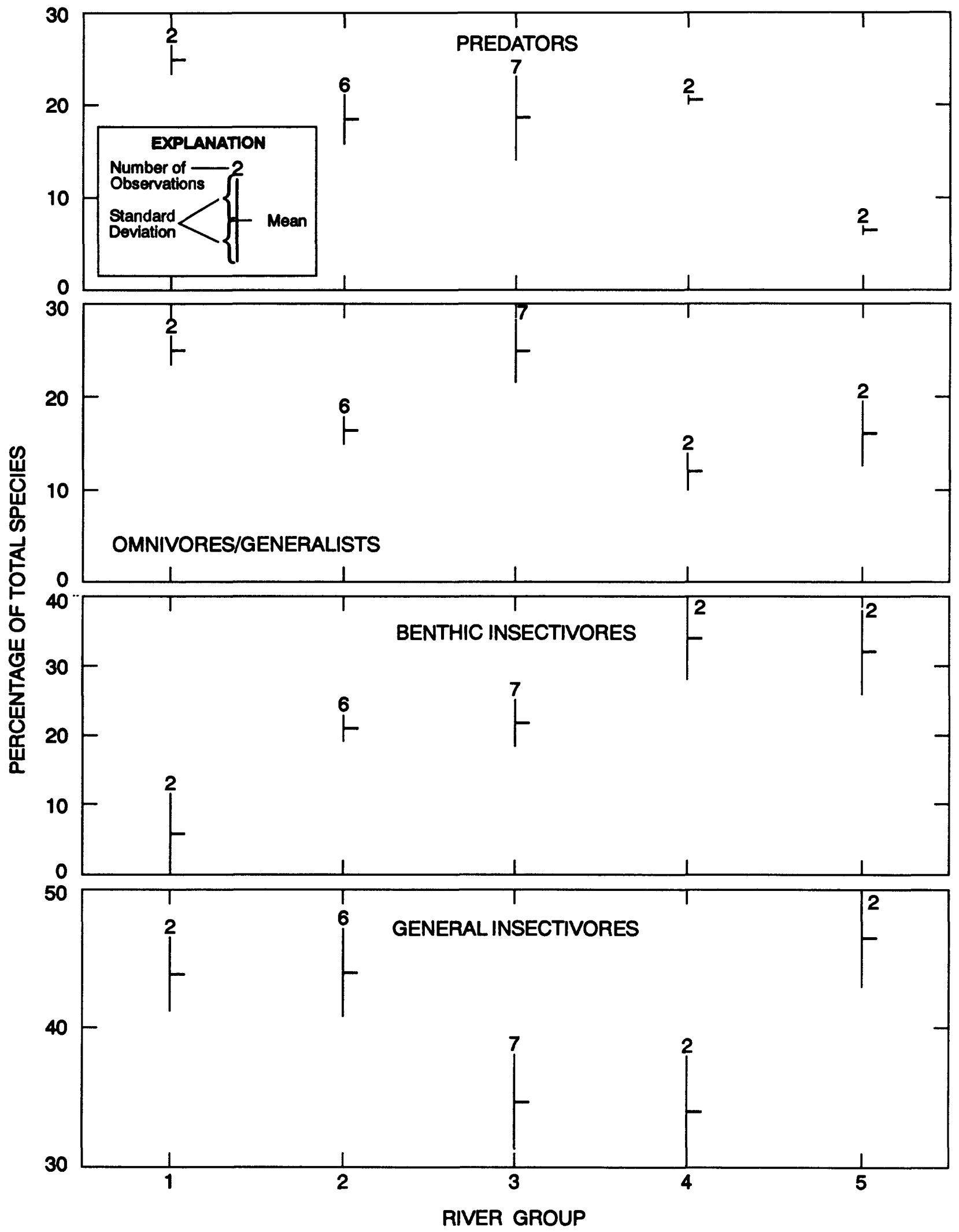

Figure 10. Percentage of specles within trophic groups among river groups Identified by cluster analysis, Red River of the North Basin. 


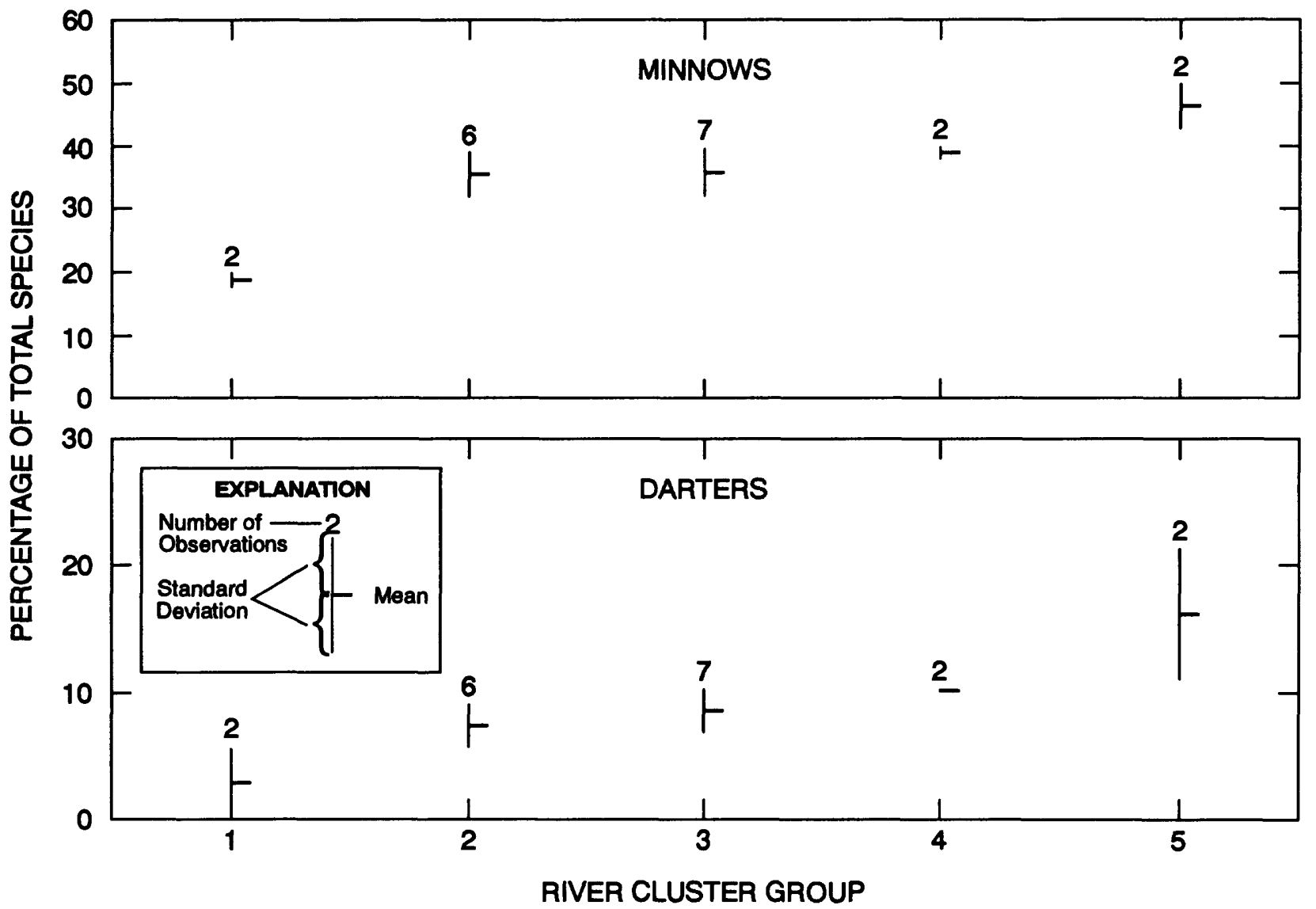

Figure 11. Percentage of specles within taxonomic groups among rlver groups Identified by cluster analysis, Red River of the North Basin.

species richness and watershed area relations in the Red River Basin.

The ranges of species richness can be classified according to the number of ecoregions a river flows through (fig. 8): one ecoregion-less than 20 species of fish, two ecoregions-20 to 30 species of fish, and three ecoregions - 38 to 60 species of fish. However, when each of the rivers is grouped by the number of ecoregions the rivers flow through, it appears that there is no general increase of species richness with watershed area. If a line is fitted to the points on figure 8 for all the rivers that flow through one ecoregion, there is not a clear increase of species richness with basin area, similarly for the other two groups of rivers that flow through two or three ecoregions. This would indicate that the number of species found had no relation to the watershed area which appears contrary to the relation defined in figure 7 . It is also contrary to the apparent tendency of the watershed size to increase with the number of ecoregions a river flows through (fig. 8).
It may be that the number of ecoregions is just too broad a measure and encompasses many more factors that, if tested, could show a more definite relation with species richness. Moreover, the number of ecoregions is a discrete or step variable, not a continuous function, and so sensitivity is lost because there is limited gradation for comparison.

The cluster analysis identified five river groups (fig. 9). River groups 1 and 5 contain rivers with low species richness (less than 20 species). The Wild Rice (North Dakota) and Elm Rivers (river group 1) tend to be intermittent while the Thief and Middle Rivers (river group 5) drain a common wetland area. Both the Thief and Middle Rivers drain small basins and contain species richness within the values predicted by the species richness-watershed area relation (fig. 7). In river group 1, the Elm River contains species richness within the values predicted by the relationship, but the Wild Rice (North Dakota) does not. Other factors in the Wild 
Rice (North Dakota) basin may be affecting species richness in this river.

River group 2 contains the rivers with the greatest number of species (generally greater than 40 ). The Sheyenne River and the Red River of the North are large rivers and would be expected to contain many species. Most of the other rivers in this group (Otter Tail, Wild Rice (Minnesota), and Buffalo Rivers) are identified as outliers containing more species than predicted based on watershed area alone (fig. 7). These rivers drain large watersheds and flow through two or three ecoregions, but other factors probably also promote greater species richness.

River group 3 contains rivers with 20-30 fish species. Most contain the number of species predicted by the species richness-watershed area relation. The exception is the Maple River, which contains fewer species than predicted. The Maple River is almost in a separate cluster group of its own (fig. 9). Its relative distance (y axis in fig. 9) from the other rivers in river group 3 is larger than any of the other rivers in the cluster. This river is different from the other rivers in group 3 with respect to the number and types of fish species found.

River group 4 contains two rivers, the Clearwater and Roseau Rivers, with 21 and 29 species of fish, respectively. Both rivers contain fewer species than expected based on watershed area alone. There probably are some factors associated with the Northern Minnesota Wetland ecoregion that affect species richness in these rivers.

The cluster analysis identified groups of rivers with similar fish species communities. The analysis distinguished these groups of rivers not only by the commonality of species, but also with respect to the species richness-watershed area relation. River groups 1 and 5 contained few species because they are relatively small rivers with small watersheds. Additionally, the rivers in group 1 tend to be intermittent and have fewer species of darters and benthic insectivores. The Wild Rice River (North Dakota) contained no darters. The rivers in group 5 have headwaters in a common wetland and have few predator species, and no bass or sunfish species. River group 3 contained rivers with species richness in accord with the watershed area relation. The two remaining river groups, 2 and 4 , contained species richness that differed from that predicted by the species richness-watershed area relation. River group 2 contained rivers with greater species richness than expected, while group 4 contained rivers with less species richness than predicted.

The rivers in river group 2 all flow through two or three ecoregions on the Minnesota side of the Red River.
These are the Red River Valley, North Central Hardwood Forest, and Northern Lakes and Forest ecoregions. The characteristics of the latter two ecoregions (table 2) that favor increased biodiversity include an abundance of aquatic macrophytes, higher stream gradients, coarser substrates, and greater abundance and diversity of geomorphological units such as pools, runs, and riffles. Water quality of streams in these ecoregions can be characterized as typically having lower nutrient concentrations and specific conductance and more neutral $\mathrm{pH}$ than the other ecoregions (table 2). The rivers in cluster group 4 contained fewer than expected species. The rivers in group 4 flow through the Northern Minnesota Wetland ecoregion. Rivers in this ecoregion tend to have low stream gradient and reduced diversity of geomorphological units as compared to other Minnesota ecoregions, except for the Red River Valley (table 2). These factors may contribute to the lower species richness than expected.

The majority of the rivers on the North Dakota side of the Red River flow through both the Red River Valley and Northern Glaciated Plains ecoregions. In comparison to the rivers in river group 2, rivers flowing through these ecoregions contain fewer aquatic macrophytes, lower stream gradients, finer substrates, and reduced diversity of geomorphological units. Water quality typically is characterized by higher nutrient concentrations, specific conductance and $\mathrm{pH}$. These factors contribute to explaining the differences in species richness among such rivers as the Wild Rice (North Dakota) and Maple Rivers and the measured deviations in the species richness-watershed area relation in the Red River Basin, where species richness is lower in North Dakota rivers than in similar sized Minnesota rivers.

The fish communities in various parts of the Red River Basin have both similarities and differences. Most species assemblages contain a core of common species found throughout the Red River Basin. Whereas approximately half the core species (northern pike, carp, white sucker, common shiner, and walleye) are migratory during spawning, the others (creek chub, blacknose dace, black bullhead, brook stickleback, and blackside and johnny darters) are not. Spawning migratory patterns are not sufficient to explain the ubiquitous distributions. Differences in species assemblages likely are associated with numerous factors which include: (1) the types and amounts of various habitats differ, (2) the number of ecoregions the rivers flow through, (3) the amount of anthropogenic disturbance, and (4) the ability of each species to expand its range by colonization of new areas when 
environmental conditions are favorable. These species assemblages are not constant. They appear to change through time as evidenced by the changing distributions of species previously noted. Hydrologic and climatic variability may be important factors in contributing to changing distributions.

\section{Contaminants in Fish}

Contaminants in fish have been documented from throughout the United States (Henderson and others, 1969; Henderson and others, 1971; Schmitt and others, 1981; Schmitt and others, 1983; Schmitt and others, 1985; and Schmitt and Brumbaugh, 1990). In 1967 the U.S. Fish and Wildlife Service began monitoring contaminants in fish through the National Pesticide Monitoring Program which later became the National Contaminant Biomonitoring Program (NCBP). This program reported concentrations of various contaminants in fish periodically from over a hundred sites in the major aquatic resources of the United States. The contaminants of major concern were trace elements (arsenic, cadmium, copper, lead, mercury, selenium, and zinc), and organic compounds (organochlorines). This program reported data from a single site in the Red River at Noyes, Minnesota near the Canadian border. The U.S. Environmental Protection Agency (USEPA) conducted a National Study of Chemical Residues in Fish (U.S. Environmental Protection Agency, 1992a and 1992b). This study was conducted over several years and contained data from fish collected near Pembina, North Dakota near the Canadian border. This site is consistent with and close to the site sampled by the U.S. Fish and Wildlife Service. The USEPA study concentrated primarily on organic compounds but included mercury. The MNDNR also has analyzed tissues of fish from the Red River.

Although these studies have determined that fish from the Red River contain contaminants, there have been no reports of acute effects or fish kills due to contaminants in the Red River Basin during recent years. A bioassay study of effluents in the Red River Basin found potential toxicity at a few selected sites, but the chemical data collected at the time of the bioassays did not show a definite causal factor (Braidech and Monro, 1988).

\section{Trace Elements}

The NCBP analyzed fish for arsenic, cadmium, copper, lead, mercury, selenium, and zinc from sauger, a predatory species, and carp, a benthic or bottom feeder. The most recent results from 1976 through 1984 are summarized by Schmitt and Brumbaugh (1990). Data from 1986 were provided by the U.S. Fish and Wildife Service (Stan Smith, U.S. Fish and Wildlife Service, written commun., 1992). Chemical analyses were performed on whole body composite samples of three to five individuals. Results were reported as micrograms/gram (parts per million) wet weight (table 6).

Arsenic During 1978 through 1984, arsenic concentrations in fish tissues declined significantly on a national basis (Schmitt and Brumbaugh, 1990). The geometric mean (mean of the logarithms transformed back to original units) concentration from all sites sampled as part of the NCBP was 0.14 parts per million (ppm) wet weight in 1984. Sauger and carp from the Red River (table 6) contained levels of arsenic below the national (NCBP) geometric mean. In 1986 the levels of arsenic appeared to increase over previous sampling years in Red River fish.

Cadmium During 1978 through 1986, cadmium concentrations in fish tissues declined significantly across the country (Schmitt and Brumbaugh, 1990). The 1984 geometric mean concentration of cadmium in fish tissues collected for the NCBP was $0.03 \mathrm{ppm}$. While Red River sauger contained cadmium below this level, carp contained higher levels (table 6). The U.S. Fish and Wildlife Service is concerned about cadmium concentrations in migratory waterfowl at the Kelly's Slough National Wildlife Refuge (NWR) west of Grand Forks, North Dakota (Joel Medlin, Field Supervisor, U.S. Fish and Wildlife Service, written commun., 1994). Concentrations of cadmium in duck livers in 1991 averaged $1.13 \mathrm{ppm}$ dry weight. Although concentrations were lower in 1992 (average of $0.21 \mathrm{ppm}$ dry weight), the U.S. Fish and Wildlife Service has identified cadmium as a potential problem at Kelly's Slough NWR.

Copper Copper concentrations in fish did not significantly change nationally during 1978 through 1984 (Schmitt and Brumbaugh, 1990). The national geometric mean concentration for this period in the NCBP was 0.65 ppm (Schmitt and Brumbaugh, 1990). Copper concentrations in Red River fish were highly variable during this period and in 1986 as well (table 6).

Lead Results of the NCBP indicated that from 1978 through 1984 lead concentrations in fish tissues steadily declined nationally (Schmitt and Brumbaugh, 1990). The amount of the decline was greater than that of any other element investigated in the program and may be attributed to the decreased use of lead in fuels. Although the trend occurred in Red River fish from 1978 through 1984, it did not continue in Red River fish in 1986 (table 6). 
Table 6.--Trace element concentrations (parts per million) in fish collected from the Red River of the North at Noyes, Minnesota, 1978 through 1986

[Data from U.S. Fish and Wildife Service, National Contaminant Biomonitoring Program, and Schmitt and Brumbaugh, 1990; --, carp not analyzed In 1980]

\begin{tabular}{|c|c|c|c|c|}
\hline \multirow[b]{2}{*}{ Element and species } & \multicolumn{4}{|c|}{ Year $^{1}$} \\
\hline & 1978 & 1980 & 1984 & 1986 \\
\hline \multicolumn{5}{|l|}{ Arsenic } \\
\hline Sauger & 0.08 & 0.06 & 0.02 & 0.11 \\
\hline Carp & .05 & - & .05 & .12 \\
\hline \multicolumn{5}{|l|}{ Cadmiunı } \\
\hline Sauger & .01 & .01 & 0 & 0 \\
\hline Carp & .15 & -- & .10 & .12 \\
\hline \multicolumn{5}{|l|}{ Copper } \\
\hline Sauger & .30 & .40 & .45 & 4.81 \\
\hline Carp & 1.40 & -- & 1.46 & .75 \\
\hline \multicolumn{5}{|l|}{ Lead } \\
\hline Sauger & .29 & .10 & .01 & .16 \\
\hline Carp & .33 & -- & .06 & .08 \\
\hline \multicolumn{5}{|l|}{ Mercury } \\
\hline Sauger & .58 & .48 & .26 & .22 \\
\hline Carp & .16 & -- & .11 & .12 \\
\hline \multicolumn{5}{|l|}{ Selenium } \\
\hline Sauger & .14 & .25 & .24 & .28 \\
\hline Carp & .60 & -- & .47 & .48 \\
\hline \multicolumn{5}{|l|}{ Zinc } \\
\hline Sauger & 27.0 & 17.9 & 15.5 & 15.3 \\
\hline Carp & 82.0 & -- & 69.1 & 70.1 \\
\hline
\end{tabular}

${ }^{1}$ No data from 1979, 1981-1983, and 1985.

Mercury During 1978 through 1984 the national geometric mean concentration of mercury $(0.10 \mathrm{ppm})$ did not change (Schmitt and Brumbaugh, 1990). The concentration of mercury in Red River carp was similar to and, in sauger, greater than the national geometric mean (table 6). Analyses by USEPA as part of the National Study of Chemical Residues in Fish (U.S. Environmental Protection Agency, 1992b) found mercury levels of $0.35 \mathrm{ppm}$ in sauger, $0.32 \mathrm{ppm}$ in channel catfish, and $0.91 \mathrm{ppm}$ in walleye from 1984 samples. More recently, the MNDNR and Minnesota Department of Health collected and analyzed catfish samples from the Red River near Wahpeton/Breckenridge and Fargo/Moorhead. These sites are upstream of both the NCBP and USEPA sites. The 1990 samples contained mercury concentrations ranging from $0.32 \mathrm{ppm}$ to $1.3 \mathrm{ppm}$ (Mark Briggs, Minnesota Department of Natural Resources, written commun., 1994). The NCBP analyses involved whole fish, whereas both the USEPA and MNDNR samples consisted of fillets which may account for the higher concentrations found in the latter two sets of analyses. Based on their analyses, the Minnesota Department of Health and the North Dakota Department of Health and Consolidated Laboratories have issued and maintain fish consumption advisories (Minnesota Department of Health, 1993, North Dakota Department of Health and Consolidated Laboratories, 1994).

Selenium During 1978 through 1984, mean selenium concentration in fish tissues declined nationally (Schmitt and Brumbaugh, 1990). In 1984 the national geometric mean concentration was $0.42 \mathrm{ppm}$. 
Sauger samples from the Red River were below this level while carp tissues were slightly above (table 6). Concentrations remained similar in 1986. The U.S. Fish and Wildlife Service is concerned about selenium concentrations in migratory waterfowl from National Wildlife Refuges within the Red River Basin (Joel Medlin, Field Supervisor, U.S. Fish and Wildlife Service, written commun., 1994). Of particular concern is Lake Ardoch NWR. Lake Ardoch is an impoundment on the Forest River in North Dakota. Although selenium concentrations in duck livers approach levels associated with toxicity (greater than $20.0 \mathrm{ppm}$ dry weight), concentrations in carp from Lake Ardoch (mean of 0.36 ppm wet weight, based on 15 whole body samples) are comparable to levels found in Red River fish (table 6).

Zinc-Concentrations of zinc were not significantly different in fish tissues nationally during 1978 through 1984 as determined by the NCBP (Schmitt and Brumbaugh, 1990). In 1984 the national geometric mean concentration was $21.7 \mathrm{ppm}$. Generally, sauger from the Red River had concentrations below the mean, while carp had concentrations above the mean (table 6). Concentrations did not change much between 1984 samples and 1986 samples.

\section{Organochlorine Compounds}

Organochlorine compounds are primarily pesticides. They may reach surface waters through precipitation runoff or through ground water, and may affect nontarget aquatic orgamisms. Biologically, they may accumulate in tissues (most are soluble in lipids) and affect the health or reproduction of fish as well as become a potential human health hazard when these fish are consumed.

$D D X \longrightarrow$ DDT (dichlorodiphenyltrichloroethane) and its metabolites DDE and DDD (all p-p' forms) have been found in Red River fish throughout the monitoring programs by NCBP, USEPA, and MNDNR. Analytical methods have changed since the beginning of the NCBP in the late 1960's such that results are not strictly comparable due to differences in analytical technique, but they may be used for trend analysis. In 1972, DDT use was banned in the United States. Since that time concentrations of DDT and its metabolites have decreased nationally (Schmitt and others, 1985; Schmitt and others, 1990). Concentrations of DDT, DDE, and DDD in fish from the Red River have followed this trend (Tornes and Brigham, 1994). The most recent samples from the NCBP (1986 data provided by the U.S. Fish and Wildlife Service) indicated low mean concentrations of all DDX compounds in sauger (DDT, $0.0 \mathrm{ppm}$; DDE, $0.04 \mathrm{ppm}$; and DDD, $0.04 \mathrm{ppm}$ ).
$P C B$ s Polychlorinated biphenyls are composed of aroclor compounds with differing percentages of chlorination. The greater the percent of chlorination, the more resistent the compound is to environmental degradation (U.S. Environmental Protection Agency, 1992a). Trend analysis from the NCBP (Schmitt and others, 1990) indicated that PCBs have decreased nationally since 1976 . This trend is evident in the Red River where total PCBs (the sun of aroclor 1242, 1248, 1254 , and 1260) have decreased from $1.20 \mathrm{ppm}$ to 0.20 ppm in sauger (Schmitt and others, 1983, p. 35; Schmitt and others, 1990, p. 772). The MNDNR sampled channel catfish from the Wahpeton/Breckenridge and Fargo/Moorhead areas in 1990. That analysis indicated PCBs in the range of 37 to 180 parts per billion (ppb) in channel catfish fillets. Although the concentrations of PCBs are declining, the Minnesota Department of Health maintains a consumption advisory for fish from the Red River (Minnesota Department of Health, 1993).

Chlordane-The components of technical chlordane include trans and cis chlordane, trans and cis nonachlor, oxychlordane, and heptachlor. Cis-chlordane and transnonachlor are the most environmentally persistent components (Schmitt and others, 1990). Results of the NCBP indicated that nationally, mean concentrations of chlordane declined from 1980 to 1984 (Schmitt and Brumbaugh, 1990). The NCBP reported $0.01 \mathrm{ppm}$ of trans and cis chlordane and trans and cis nonachlor in Red River sauger in 1984. The USEPA reported comparable concentrations from channel catfish $(0.02$, $0.02,0.02$, and $0.008 \mathrm{ppm}$, respectively) (U.S.

Environmental Protection Agency, 1992b, p. D-5-3 and D-5-21).

Other organochlorine compounds detected in Red River fish by the above studies include dieldrin, $\mathrm{HCH}$, endrin, and toxaphene. None of these compounds were detected in the 1986 sauger samples analyzed as part of the NCBP.

\section{Summary}

The U. S. Geological Survey is conducting a National Water Quality Assessment. The Red River of the North Basin is one of 60 study units that compose the assessment. The goals of the program are to provide a nationally consistent description of current waterquality conditions; define long-term trends; and identify, describe, and explain major factors affecting observed conditions.

Since human settlement about 150 years ago, the Red River Basin has become a major agricultural area for production of wheat and other small grains.

Approximately 74 percent of the land is agricultural. 
Lack of topographic relief (525 meters across the United States portion of the basin) has contributed to poor drainage and flooding, which have been addressed by the construction of nunierous dams and drainage ditches.

Most of the 75 fish species found in the Red River Basin probably colonized the area from the Mississippi River drainage after the last ice age while glacial Lake Agassiz drained through the Minnesota River Valley. Only one non-native species, the carp, has invaded the basin although some native and exotic species are stocked in different parts of the Red River Basin to augment sport fishing. Sport fishing for channel catfish in the Red River is internationally known.

Fish species are not equally distributed throughout the basin. Twenty-two more species are found in the eastern portion of the basin (Minnesota) than in the western portion (North Dakota). The Otter Tail River in Minnesota, which flows through three ecoregions, contains more fish species (60) than any other river in the Red River Basin. Seventeen of the 22 species found only in Minnesota are found in the Otter Tail River and six are found only in the Otter Tail River.

The number of fish species increases with the size of the river (measured by drainage area) and the number of ecoregions which the river flows through. A cluster analysis identified five river groups based on similarity of fish species composition. The groups appear to correlate with stream size and ecoregions. Five river groups identified by cluster analysis could be distinguished by the relative abundance of species within various trophic and taxononic groups. Trophic differences were evident based on the number of species classified as predators, omnivores, benthic insectivores, and general insectivores. Although there were no differences in the number of species in the bass and sunfish family or the sucker family, the number of species in the minnow family and the darter subfamily were different among the river groups.

Trace elements (arsenic, cadmium, copper, lead, mercury, selenium, and zinc) in fish tissues from the Red River were generally below national averages and tended to be consistent or decrease through time. Mercury concentrations in fish tissues are still a human health concern. Organochlorine compounds (DDT and metabolites, PCBs, and chlordane) were all found at low levels in Red River fish. Concentrations tended to decline with time, but PCB concentrations are still a human health concern.

\section{References Cited}

Anderson, C.P., Erickson, J.E., Ross, Jon, and Underhill, J. C., 1977, Revised distribution records of some Minnesota fishes: Journal of the Minnesota Academy Sciences, v. 43, p. 3-6.

Baxter, R.M., 1977, Environmental effects of dams and impoundments: Annual Review Ecology and Systematics, v. 8, p. 255-283.

Bott, T.L., Brock, J.T., Dunn, C.S., Naiman, R.J., Ovink, R. W., and Petersen, R.C., 1985, Benthic community metabolism in four temperate stream systems: an inter-biome comparison and evaluation of the river continuum concept: Hydrobiologia, v. 123, p. 3-45.

Braidech, T.E., and Monro, D.J., 1988, Red River toxic profile study: International Red River Pollution Board, $23 \mathrm{p}$.

Carlander, K.D., 1977, Handbook of freshwater fishery biology, volume 2: Iowa State University Press, Ames, Iowa, $431 \mathrm{p}$.

Cohen, Phillip, Alley, W.M., and Wilber, W.G., 1988, National water-quality assessment: future directions of the U.S. Geological Survey: Water Resources Bulletin, v. 46, no. 6, p. 1147-1151.

Coffin, Barbara, and Pfannmuller, Lee, 1988, Minnesota's endangered flora and fauna: University of Minnesota Press, St. Paul, 473 p.

Cummins, K.W., and Merritt, R.W., 1984, Ecology and distribution of aquatic insects, in R.W. Merritt and K.W. Cummins, ed., An introduction to the aquatic insects of North America: Kendall/Hunt Publishing Co., Dubuque, Iowa, p. 59-65.

Cvancara, A.M., 1970, Mussels (Unionidae) of the Red River Valley in North Dakota and Minnesota, U.S.A.: Malacologia, v. 10, no.1, p. 57-92. 1983, Aquatic mollusks of North Dakota: North Dakota Geological Survey Report of Investigation No. 78,128 p., 6 plates.

Dawley, Charlotte, 1947, Distribution of aquatic mollusks in Minnesota: American Midland Naturalist v. 38, p. 671-697. 
Eddy, Samuel, Tasker, R.C., and Underhill, J.C., 1972, Fishes of the Red River, Rainy River, and Lake of the Woods, Minnesota, with comments on the distribution of species in the Nelson River drainage: James Ford Bell Museum of Natural History, Occasional Papers, No. 11, 24 p.

Eddy, Samuel, and Underhill, J.C., 1974, Northern fishes: University of Minnesota Press, Minneapolis, Minnesota, 414 p.

Edwards, R.R., 1978, The effect of hypolimnion reservoir releases on fish distribution and species diversity: Transactions American Fisheries Society. v. 107, p. 71-77.

Elson, J.A., 1967, Geology of glacial Lake Agassiz, in Mayer- Pales. W.J., ed., Life, land and water: University of Manitoba Press, Winnipeg, p.37-95.

Enblom, J.W., 1982, Fish and wildlife resources of the Roseau River: Minnesota Department of Natural Resources Special Report No. 130, 95 p., 3 plates.

Erman, D.C., 1973, Upstream changes in fish populations following impoundment of Sagehen Creek, California: Transactions American Fisheries Society, v. 102, p. 626-629.

Etnier, D.A., 1972, The effect of annual rechanneling on a stream fish population: Transactions American Fisheries Society, v. 101, p. 372-375.

Fandrei, Gary, Heiskary, Steve, and McCollar, Sylvia, 1988, Descriptive characteristics of the seven ecoregions in Minnesota: Minnesota Pollution Control Agency, $140 \mathrm{p}$.

Gelroth, J.V., and Marzolf, G.R., 1978, Primary production and leaf-litter decomposition in natural and channelized portions of a Kansas stream: American Midland Naturalist, v. 99, p. 238-243.

Goldstein, R.M., 1981, Longitudinal succession in impact assessment of river system fish communities: Water Resources Bulletin, v. 17, p. 75-81.

Grizzle, J.M., 1981, Effects of hypolimnetic discharge on fish health below a reservoir: Transactions American Fisheries Society, v. 110, p. 29-43.
Gurtz. M. E., 1994, Design of the biological components of the National Water- Quality Assessment (NAWQA) program, in Loeb, S. L. and Spacie, Anne, ed., Biological monitoring of aquatic systems: CRC Press, Lewis Publishers, Boca Raton, p. 323-354.

Hanson, S.R., Renard, P.A., Kirsch, N.A., and Enblom, J.W., 1984, Biological survey of the Otter Tail River: Minnesota Department of Natural Resources Special Publication No. 137, 101 p., 10 plates.

Harrel, R.C., Davis, B.J., Dorris, T.C., 1967, Stream order and species diversity of fishes in an intermittent Oklahoma stream: American Midland Naturalist, v. 78, p. 428-436.

Henderson, Croswell, Johnson, W.L., and Inglis, Anthony, 1969, Organochlorine insecticide residues in fish, National Pesticide Monitoring Program: Pesticides Monitoring Journal, v. 3, p. 145-171.

Henderson, Croswell, Inglis, Anthony, and Johnson, W.L., 1971, Organochlorine insecticide residues in fish-Fall 1969, National Pesticide Monitoring Program, Pesticides Monitoring Journal, v. 5, p. 111.

Hubbs, C.L., and Lagler, K.F., 1958, Fishes of the Great Lakes region: Bulletin Cranbrook Institute Science, no. 26, p. 1-213.

Hughes, R.M., and Gammon, J.R., 1987, Longitudinal changes in fish assemblages and water quality in the Willamette River, Oregon: Transactions American Fisheries Society, v. 116, p. 196-209.

Hynes, H.B.N., 1970, Ecology of running water: University of Toronto Press, Toronto, 555 p.

Karr, J.R., 1981, Assessment of biotic integrity using fish communities: Fisheries, v. 6. p. 21-27.

Karr, J.R., Fausch, K.D., Angernieier, P.L., and Schlosser, I.J., 1986, Assessing biological integrity in running waters: a method and its rationale: Illinois Natural History Survey Special Publication Number 5, $28 \mathrm{p}$. 
Leahy, P.P., Rosenshein, J.S., and Knopman, D.S., 1990 , Implementation plan for the National WaterQuality Assessment program: U.S. Geological Survey Open-File Report 90-174, 10 p.

Minnesota Department of Health, 1993, Minnesota Fish Consumption Advisory: Minnesota Department of Health, 72 p.

Minshall, G.W., Petersen, R.C., Cummins, K.W., Bott, T.L., Sedell, J.R., Cushing, C.E., and Vannote, R.L., 1983, Interbiome comparison of stream ecosystem dynamics: Ecological Monographs, v. 53, p. 1-25.

Naplin, R.L., Heberling, P.G., and Fierstine, H.L., 1977, Evaluation of stream characteristics and fish populations of the Wild Rice River near the proposed Twin Valley Reservoir, Minnesota: Minnesota Department of Natural Resources Special Publication No. 118, 46 p.

Neel, J.K., 1963, Impact of reservoirs, in Frey, D.G. ed., Limnology in North America, Madison, Wisconsin, p. 575-593.

Neel, J.K., 1985, A northern prairie stream: University of North Dakota Press, Grand Forks, North Dakota, 274 p.

North Dakota Department of Health and Consolidated Laboratories, 1994, Fish consumption advisoryWaters of North Dakota, 6 p.

North Dakota Game and Fish Department, 1962a, Forest River stream survey form: North Dakota Game and Fish Department Mimeograph Report, 5 p.

North Dakota Game and Fish Department, 1962b, Pembina River stream survey form: North Dakota Game and Fish Department Mimeograph Report, 5 p.

North Dakota Game and Fish Department, 1964, A revised list of the fishes of North Dakota: North Dakota Game and Fish Department Mimeograph Report, 15 p.

North Dakota Game and Fish Department, 1975a, Ecological investigations of lakes, streams and impoundments in North Dakota (surveys): Dingell-Johnson Division, Project F-2-R-21, Study II, Report No. A-1036 [variously paged].
North Dakota Game and Fish Department, 1975b, Ecological investigations of lakes, streams and impoundments in North Dakota (surveys): Dingell-Johnson Division, Project F-2-R-22, Study II, Report No. A-1041 [variously paged].

North Dakota Game and Fish Department, 1977, Ecological investigations of lakes, streams and impoundments in North Dakota (surveys): Dingell-Johnson Division, Project F-2-R-23, Study II, Report No. A-1046 [variously paged].

North Dakota Outdoors, 1986, The rare ones, v. 49, no. $2,32 \mathrm{p}$.

Omernik, J.A., and Gallant, A.L., 1988, Ecoregions of the upper midwest states: U.S. Environmental Protection Agency, EPA/600/3-88/037, 56 p.

Owen, J.B., Elsen, D.S. and Russell, G.W., 1981, Distribution of fishes in North and South Dakota basins affected by the Garrison Diversion Unit: Fisheries Research Unit, University of North Dakota, University of North Dakota Press, Grand Forks, North Dakota, 211 p.

Peterka, J.J., 1978, Fishes and fisheries of the Sheyenne River, North Dakota: Annual Proceedings North Dakota Academy Science, v. 32, part II, p. 29-44.

Peterka, J.J., 1991, Survey of fishes in six streams in northeastern North Dakota, 1991: Mimeograph Report, 16 p.

Phillips, G.L., and Underhill, J.C., 1967, Revised distribution records of some Minnesota fishes, with addition of two species to the faunal list: Journal of the Minnesota Academy of Science, $v$. 34, p. 177-180.

Plafkin, J.L., Barbour, M.T., Porter, K.D., Gross, S.K., and Hughes, R.M., 1989, Rapid bioassessment protocols for use in streams and rivers-benthic macroinvertebrates and fish: U.S. Environmental Protection Agency, EPA/440/4-89/001 [variously paged].

Reedstrom, D.C., 1967, A biological survey of the Buffalo River watershed Becker, Clay, and Otter Tail Counties: Minnesota Department of Conservation Special Publication No. 44, 79 p. 
Reedstrom, D.C., and Carlson, R.A., 1969, A biological survey of the Pelican River watershed Becker, Clay and Otter Tail Counties: Minnesota Department of Conservation Special Publication No. $65,117 \mathrm{p}$.

Renard, P.A., Hanson, S.R., and Enblom, J.W., 1983, Biological survey of the Red Lake River: Minnesota Department of Natural Resources Special Publication No. 134, 76 p., 17 plates.

Renard, P.A., Hanson, S.R., and Enblom, J.W., 1986, Biological survey of the Red River of the North: Minnesota Department of Natural Resources Special Publication No. 142, 60 p., 17 plates.

Ryckman, L.F., 1981, A revised checklist of the fishes of North Dakota, with a brief synopsis of each species distribution within the state: North Dakota Game and Fish Department Circular, 18 p.

SAS Institute Inc., 1989, SAS/STAT User's guide, Version 6, fourth edition, vol. 1: SAS Institute Inc., Cary, North Carolina, 943 p.

Schlosser, I.J., in press, Critical landscape attributes influencing fish population dynamics in headwater streams: Hydrobiologia.

Schmitt, C.J. and Brumbaugh, W.G., 1990, National Contaminant Biomonitoring ProgramConcentrations of arsenic, cadmium, copper, lead, mercury, selenium, and zinc in U.S. freshwater fish, 1976-1984: Archives of Environmental Contamination and Toxicology, v. 19, p. 731-747.

Schmitt, C.J., Ludke, J.L., and Walsch, D.F., 1981, Organochlorine insecticide residues in fishNational Pesticide Monitoring Program, 1970-74: Pesticide Monitoring Journal, v. 14, p. 136-206.

Schmitt, C.J., Ribick, M.A., Ludke, J.L., and May, T.W., 1983, National Pesticide Monitoring ProgramOrganochlorine residues in freshwater fish, 197679: U.S. Fish and Wildlife Service Resource Publication 152, $62 \mathrm{p}$.

Schmitt, C.J., Zajicek, J.L., and Ribick, M.A., 1985, National Pesticide Monitoring Program-Residues of organochlorine chemicals in freshwater fish, 1980-81: Archives of Environmental Contamination and Toxicology, v. 14, p. 225-260.
Schmitt, C.J., Zajicek, J.L., and Peterman, P.H., 1990, National Contaminant Biomonitoring ProgramResidues of organochlorine chemicals in U. S. freshwater fish, 1976-1984: Archives of Environnental Contamination and Toxicology, v.19, p. 748-781.

Scott, E.C., and Crossman, E.J., 1973, Freshwater fishes of Canada: Fisheries Research Board of Canada, Bulletin 184, 966 p.

Sheldon, A.L., 1968, Species diversity and longitudinal succession in stream fishes: Ecology, v. 49. p. 193198.

Shelford, V.A., 1911, Ecological succession, I. stream fishes and the method of physiographic analysis: Biological Bulletin v. 21, p. 9-35.

Spence, J.A., and Hynes, H.B.N., 1971, Differences in fish populations upstream and downstream of a mainstream impoundment: Journal Fisheries Research Board Canada, v. 28, p. 45-46.

Stoaks, R.D., 1975, Seasonal and spatial distribution of riffle dwelling aquatic insects in the Forest River, North Dakota: Ph. D. Dissertation, North Dakota State University, 162 p.

Stoner, J.D., 1991, National Water-Quality Assessment program-Red River of the North: U.S Geological Survey Open-File Report 91-151, 2 p.

Stoner, J.D., Lorenz, D.L., Wiche, G.J., and Goldstein, R. M., 1993, Red River of the North Basin, Minnesota, North Dakota, and South Dakota: Water Resources Bulletin v. 29, p. 575-615.

Strahler, H.N., 1957, Quantitative analysis of watershed geomorphology: American Geophysical Union Transactions, v. 33, p. 913-920.

Tornes, L.H., and Brigham, M.E., 1994, Nutrients, suspended sediment, and pesticides in waters of the Red River of the North Basin, Minnesota, North Dakota, and South Dakota, 1970- 1990: U.S. Geological Survey, Water-Resources Investigation Report 93-4231, 62 p.

Underhill, J.C., 1957, The distribution of Minnesota minnows and darters in relation to Pleistocene glaciation: Minnesota Museum of Natural History, Occasional Papers No. 7, 45 p. 
Underhill, J.C., 1986, The fish fauna of the Laurentian Great Lakes, the St. Lawrence Lowlands, Newfoundland and Labrador, in Hocutt, C.H. and Wiley, E.O., ed., Zoogeography of North American Fresh Water Fishes: John Wiley and Sons, Inc., New York, p. 105-136.

Underhill, J.C., 1989, The distribution of Minnesota fishes and late Pleistocene glaciation: Journal of the Minnesota Academy of Science, v. 55, no.1, p. 32-37.

U.S. Environmental Protection Agency, 1992a, National study of chemical residues in fish, Volume I: U.S. Environmental Protection Agency, EPA 823-R92-008a, [variously paged].

U.S. Environmental Protection Agency, 1992b, National study of chemical residues in fish, Volume II: U.S. Environmental Protection Agency, EPA 823-R-92-008b, [variously paged].

United States Geological Survey, 1974, Drainage ditch inventory - 1973: Minnesota District Report for Minnesota Department of Natural Resources. [variously paged].

Vannote, R.L., Minshall, G.W., Cummins, K.W., Sedell, J.R., and Cushing, C.E., 1980, The river continuum concept: Canadian Journal Fisheries and Aquatic Science, v. 37, p. 370-377.

Waters, T. F., 1977, The streams and rivers of Minnesota: University of Minnesota Press, Minneapolis, Minnesota, 373 p.

Woolman, A.J., 1895, A report on ichthyological investigations in western Minnesota and eastern North Dakota: Report U.S. Fish Commission (1893), p. 343-373.

Wiley, M.J., Osborne, L.L., and Larimore, R.W., 1990, Longitudinal structure of an agricultural prairie river system and its relationship to current ecosystem theory: Canadian Journal Fisheries and Aquatic Science, v. 47, p. 373-384.

Wright, H.E., Jr., 1972a, Quaternary history of Minnesota, in Sims, P.K., and Morey, G.B., ed., Geology of Minnesota: A centennial volume: Minnesota Geological Society, St. Paul, Minnesota, p. 515-560.
Wright, H.E., Jr., 1972b, Physiography of Minnesota, in Sims, P.K., and Morey, G.B., ed., Geology of Minnesota: A centennial volume: Minnesota Geological Society, St. Paul, Minnesota, p. 561578. 